OPEN ACCESS

Edited by:

Ariane Berdal,

UMRS 1138 INSERM University Paris-Diderot Team POM, France

Reviewed by:

Victor E. Arana-Chavez, University of São Paulo, Brazil

Olivier Cases,

Centre National de la Recherche

Scientifique (CNRS), France

Claudio Cantù,

University of Zurich, Switzerland

*Correspondence:

Yong-Hee P. Chun

chuny@uthscsa.edu

Specialty section:

This article was submitted to

Craniofacial Biology and Dental

Research,

a section of the journal

Frontiers in Physiology

Received: 30 April 2017

Accepted: 10 July 2017

Published: 31 July 2017

Citation:

Pham C-D, Smith CE, Hu Y, Hu JC-C,

Simmer JP and Chun Y-HP (2017)

Endocytosis and Enamel Formation.

Front. Physiol. 8:529.

doi: 10.3389/fphys.2017.00529

\section{Endocytosis and Enamel Formation}

\author{
Cong-Dat Pham ${ }^{1}$, Charles E. Smith ${ }^{2,3}$, Yuanyuan $\mathrm{Hu}^{3}$, Jan C-C. Hu ${ }^{3}$, James P. Simmer ${ }^{3}$ \\ and Yong-Hee P. Chun ${ }^{1,4 *}$
}

${ }^{1}$ Department of Periodontics, School of Dentistry, University of Texas Health Science Center at San Antonio, San Antonio, TX, United States, ${ }^{2}$ Department of Anatomy and Cell Biology, McGill University, Montreal, QC, Canada, ${ }^{3}$ Department of Biologic and Materials Sciences, University of Michigan, Ann Arbor, MI, United States, ${ }^{4}$ Department of Cell Systems \&

Anatomy, School of Medicine, University of Texas Health Science Center at San Antonio, San Antonio, TX, United States

Enamel formation requires consecutive stages of development to achieve its characteristic extreme mineral hardness. Mineralization depends on the initial presence then removal of degraded enamel proteins from the matrix via endocytosis. The ameloblast membrane resides at the interface between matrix and cell. Enamel formation is controlled by ameloblasts that produce enamel in stages to build the enamel layer (secretory stage) and to reach final mineralization (maturation stage). Each stage has specific functional requirements for the ameloblasts. Ameloblasts adopt different cell morphologies during each stage. Protein trafficking including the secretion and endocytosis of enamel proteins is a fundamental task in ameloblasts. The sites of internalization of enamel proteins on the ameloblast membrane are specific for every stage. In this review, an overview of endocytosis and trafficking of vesicles in ameloblasts is presented. The pathways for internalization and routing of vesicles are described. Endocytosis is proposed as a mechanism to remove debris of degraded enamel protein and to obtain feedback from the matrix on the status of the maturing enamel.

Keywords: endocytosis, amelogenesis, endocytic trafficking, Rab proteins, clathrin, pinocytosis

\section{ENDOCYTOSIS IN AMELOBLASTS}

Enamel formation is a unique process that coordinates the movement of proteins and ions between ameloblasts and the developing extracellular matrix (Smith and Nanci, 1996; Lacruz et al., 2013b). The extracellular matrix represents a sealed compartment between ameloblasts and the mineralized dentin without direct access to the vascular system or the connective tissue compartment (Bronckers, 2016). The transport of proteins and ions between ameloblasts and matrix for crystal mineralization is controlled by ameloblasts. As the enamel organ develops, the inner epithelial cells differentiate into polarized ameloblasts. The two key protein transport functions of ameloblasts are the secretion and the resorption of enamel proteins. Ameloblasts secrete enamel proteins at the surface of forming enamel that assemble into a scaffold to initiate and lengthen the growing mineral crystals (Smith et al., 2016). As enamel proteins are selectively cleaved by proteinases, fragments and perhaps some almost intact proteins are removed from the matrix via endocytosis by ameloblasts, a process that speeds up over time as enamel formation continues (Reith and Cotty, 1967; Smith, 1979; Kallenbach, 1980a,b). The freed up space is then utilized to widen the individual enamel ribbons. The final product contains $<5 \%$ of proteins and water (Schmitz et al., 2014). The failure of efficient removal of enamel proteins and deposition of mineral results in hypomineralized or hypomature enamel. The enamel proteins constitute the protein backbone of the enamel matrix and include amelogenin, ameloblastin, and enamelin. All of them are part of the cluster called secreted calcium-binding phosphoproteins 
(Kawasaki et al., 2004). Structurally, all enamel proteins possess a poorly defined secondary structure, a feature characteristic for intrinsically disordered proteins (Wald et al., 2017). Regions of hydrophobic residues of amelogenin facilitate protein-protein interactions resulting in assemblies of nanospheres (Fincham et al., 1995). In the absence of amelogenin, enamel ribbons lose their self-sufficiency and fuse together in fan-like structures (Smith et al., 2016). Enamel proteins are sequentially processed into fragments that are then internalized by ameloblasts (Bartlett, 2013). Initially, matrix metalloproteinase 20 cleaves enamel proteins at highly selective internal sites during the secretory stage (Fukae et al., 1998). The remaining fragments are then further degraded into smaller peptides by kallikrein4 (kallikrein related peptidase 4 ) during the maturation stage (Nagano et al., 2009).

The uptake of degraded proteins takes place throughout all stages of enamel formation (Ozawa et al., 1983). The endocytic activities of preameloblasts and ameloblasts include the removal of basement membrane proteins and enamel proteins via vesicles and their transport to lysosomes (Katchburian and Holt, 1969; Kallenbach, 1980a; Takano and Ozawa, 1980; Ozawa et al., 1983; Salama et al., 1989, 1990a,b; Smith et al., 1989; Nanci et al., 1996). The localization of amelogenin with immune gold labeling techniques has established that enamel proteins are found in large quantities in organelles with functions in endocytosis in ameloblasts of both secretory and maturation stages (Figure 1, Table 1).

Endocytosis is linked to enamel mineralization to remove processed enamel proteins from the matrix and to deposit mineral (Smith, 1979, 1998; Nanci et al., 1987a; Smith et al., 1989). The site and configuration of plasma membrane from which enamel proteins are secreted and endocytosed differ in

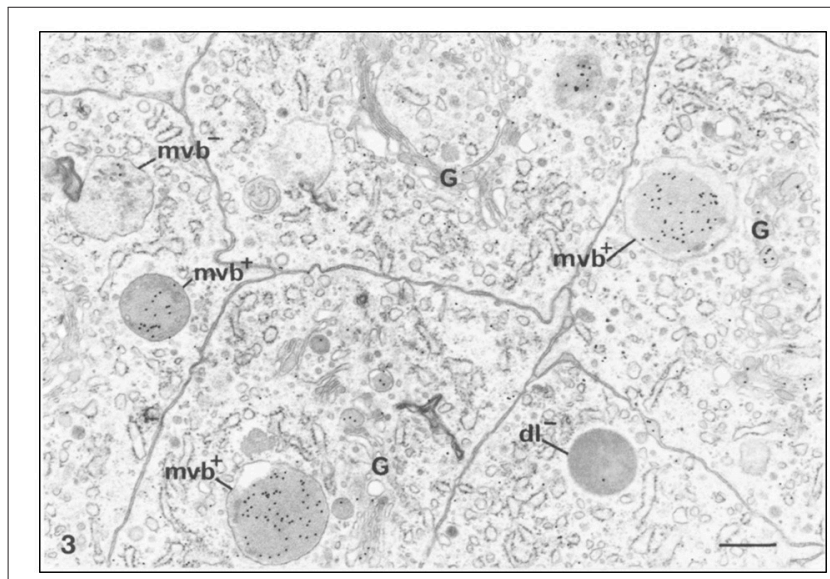

FIGURE 1 | Immunocytochemical preparation illustrating the distribution of gold labeled amelogenin over various compartments of ameloblasts from the secretion stage in mouse incisors. Lysosomes appear variably labeled. Multivesicular bodies are often intensely labeled (mvb+). An unlabeled multivesicular body (mvb-) and an unlabeled dark lysosome (dl-) are shown. The Golgi apparatus (G) shows some labeling by gold particles, × 24,875. Bar $=0.5 \mu \mathrm{m}$. Permission to reprint from: Application of High-Resolution Immunocytochemistry To the Study of the Secretory, Resorptive, and Degradative Functions of Ameloblasts by Nanci et al. (1987a). morphology depending on developmental stage. During the pre-secretory stage fragments of the degraded basal lamina are removed through finger-like cell processes penetrating into the pre-dentin (Reith, 1967; Kallenbach, 1976; Nanci et al., 1989). During secretory and maturation stages stippled material adjacent to ameloblasts is interpreted as degraded enamel proteins and their localization is indicative of resorptive activity (Kallenbach, 1980b; Ozawa et al., 1983; Nanci et al., 1987b).

With the formation of the Tomes' process on the apical membrane during secretory stage, proteins are secreted in large quantities from two growth sites, distal and proximal, to give rise to orientation of rod and interrod enamel (Nanci and Warshawsky, 1984). Both of these sites are characterized by deep membrane infoldings (Weinstock and Leblond, 1971; Kallenbach, 1973; Nanci and Warshawsky, 1984; Uchida and Warshawsky, 1992; Kim et al., 1994). Vesicles with granular content to be secreted are found in close proximity to infoldings suggesting that a membrane fusion event between vesicle and infolding results in the discharge of the luminal content of the vesicle into the channel of the infolding (Simmelink, 1982). The enamel proteins then could escape through the channels between the infoldings to the outer surface of the secretory face (Figures 2, 3). Conversely, it is conceivable that endocytosis could occur in the reverse direction, inside the membrane infolding similar to a tubular network (Smith, 1979). The space inside an infolding ranges from small and narrow to bloated and filled with granular material (Kallenbach, 1974; Nanci et al., 1987b). This mechanism allows several vesicles to fuse in a limited area of the cell surface and to release and internalize material in large quantities. Enamel ribbons are bundled and closely related to the openings of the infoldings and extend in the direction of the opening (Nanci and Warshawsky, 1984). The ameloblast surface seems to be less infolded when there is loss of function of any one of the enamel matrix scaffold proteins (Smith et al., 2016). In the maturation stage, ameloblasts acquire a ruffle-ended membrane $80 \%$ of the time compared to smooth-ended borders. Ruffleended ameloblasts are more absorptive than smooth-ended ameloblasts (Nanci et al., 1987b). The ruffle-ended membrane forms a complex, infolded apical surface constantly changing its configuration.

In addition to endocytosis of enamel proteins from the apical membranes of secretory and maturation stage ameloblasts, some small amounts of enamel matrix proteins are secreted and endocytosed from the lateral extracellular spaces between the cells (Nanci and Smith, 1992). Granular material containing amelogenin has been found in accumulations between the tight junctions of secretory stage ameloblasts (Nanci and Warshawsky, 1984; Nanci et al., 1987a). These "patches" are associated with sites of the ameloblasts membrane that lack membrane infoldings and mineralization. It was suggested that the microenvironment of rod and interrod growth sites is unique for the initiation of mineralization (Nanci et al., 1987c). At the lateral surfaces pinocytosis is frequently observed (Figure 3).

The packing of vesicles for secretion and endocytosis is a membrane consuming process altering the surface area. Given the large quantity of secreted enamel proteins, the gain of membrane during fusion events could alter the shape of the 
TABLE 1 | Density of gold labeling over enamel and organelles in ameloblasts following incubations with anti-amelogenin antibody ${ }^{a}$.

\begin{tabular}{|c|c|c|c|}
\hline \multirow[t]{2}{*}{ Compartment } & \multicolumn{3}{|c|}{ Density of labeling ${ }^{b}$} \\
\hline & Early secretion (mouse) & Mid secretion (rat) & Early maturation (rat) \\
\hline Enamel & $129.9 \pm 9.4$ & $121.4 \pm 9.6$ & $80.0 \pm 3.9$ \\
\hline Rough endoplasmic reticulum & $7.2 \pm 0.4$ & $8.4 \pm 0.4$ & $9.2 \pm 0.4$ \\
\hline Golgi saccules & $17.7 \pm 0.8$ & $15.1 \pm 1.0$ & $9.8 \pm 0.6$ \\
\hline Secretory granules & $154.7 \pm 10.9$ & $137.6 \pm 8.3$ & $137.0 \pm 14.5$ \\
\hline Dark lysosomes & $16.1 \pm 3.3$ & $8.5 \pm 0.7$ & $5.9 \pm 0.5$ \\
\hline Pale lysosomes & $14.8 \pm 2.9$ & $11.1 \pm 0.9$ & $9.8 \pm 1.2$ \\
\hline Multivesicular bodies & $19.8 \pm 3.8$ & $37.0 \pm 3.5$ & $26.9 \pm 1.3$ \\
\hline Mitochondriac $^{\mathrm{C}}$ & $3.9 \pm 0.7$ & $3.8 \pm 0.6$ & $4.1 \pm 0.2$ \\
\hline
\end{tabular}

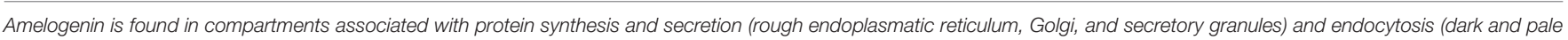
lysosomes, and multivesicular bodies) pathways.

a Data modified from Nanci et al. (1985, 1987b).

${ }^{b}$ Number of particles / $\mu m^{2} \pm S E M$.

${ }^{c}$ Index of background labeling.

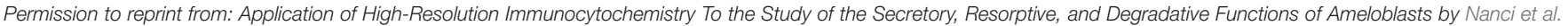
(1987a).

A

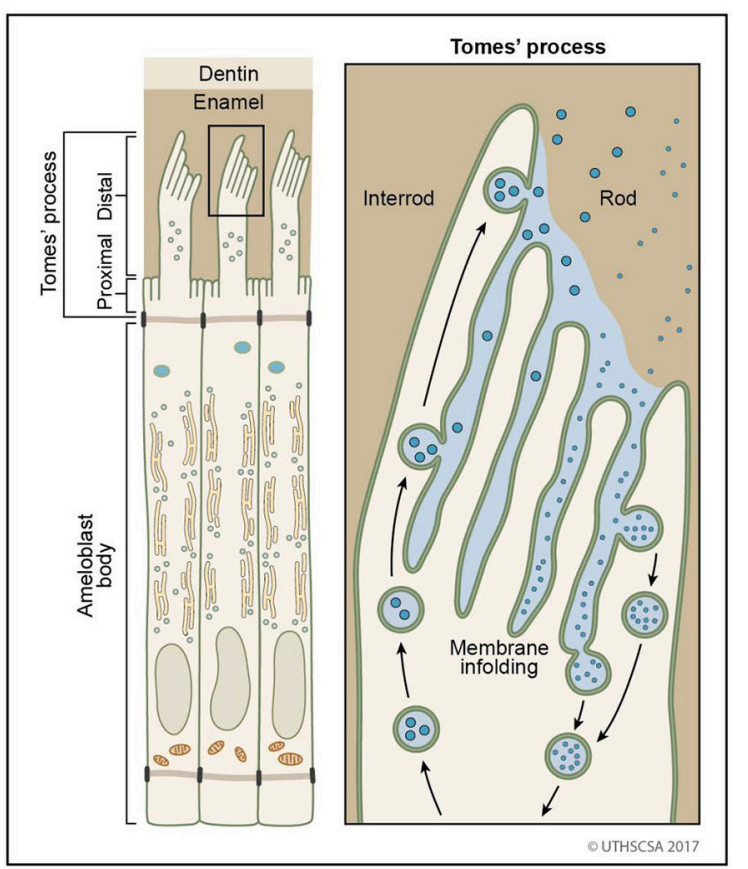

B

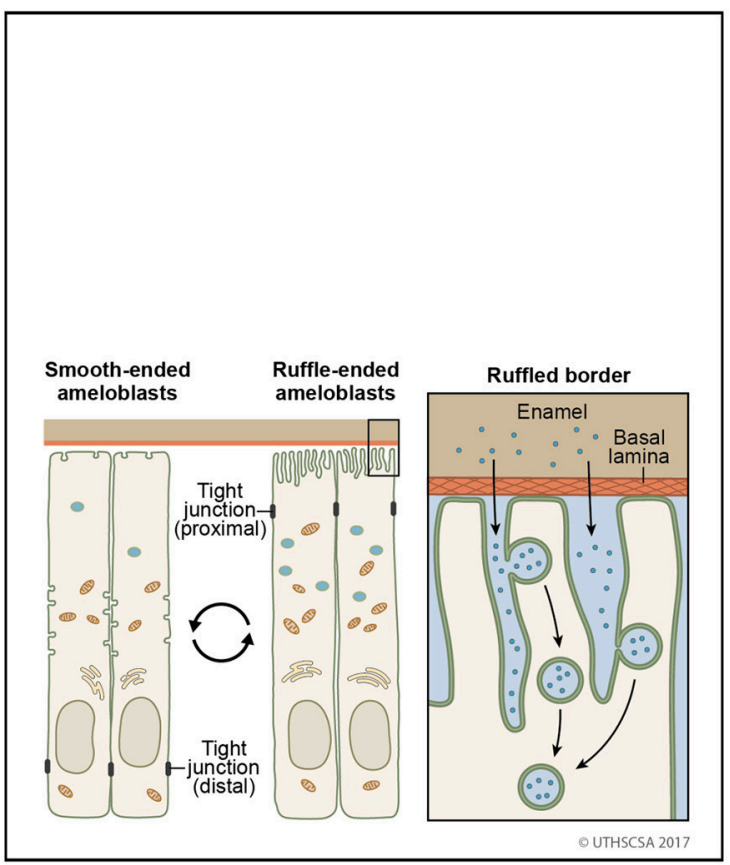

FIGURE 2 | Sites of secretion and endocytosis of the ameloblast membrane. (A) The secretory ameloblasts forms a Tomes' process from the apical membrane with a proximal portion and a distal portion. The proximal portion is associated with formation of interrod enamel, the distal portion with rod enamel formation. Vesicle fusion can be observed on the surface membrane adjacent to the rod growth site. Many vesicles fuse (secretion) or originate (endocytosis) from membrane infoldings found on the proximal portion and the distal portion. (B) In the maturation stage, degraded enamel proteins are internalized by ameloblasts. Ameloblasts modulate between smooth-ended and ruffle bordered membranes. In $80 \%$ of the maturation stage, ameloblasts are ruffle-ended with deep membrane invaginations. Degraded enamel proteins from the enamel matrix permeate the area between convoluted tubules and are resorbed via vesicles.

cell. However, for the Tomes' process maintaining the shape is critical to allow a defined mineralization front. By fusing with the membrane of infoldings or ruffles, membrane is recycled and the outer plasma membrane is not affected. As a result, infoldings and ruffles become longer and branched (Nanci and Smith, 1992).

\section{ENDOCYTOSIS TYPES, MECHANISMS, PATHWAYS}

Endocytosis is a form of active, energy-using transport of extracellular molecules internalized by a cell into vesicles. As 

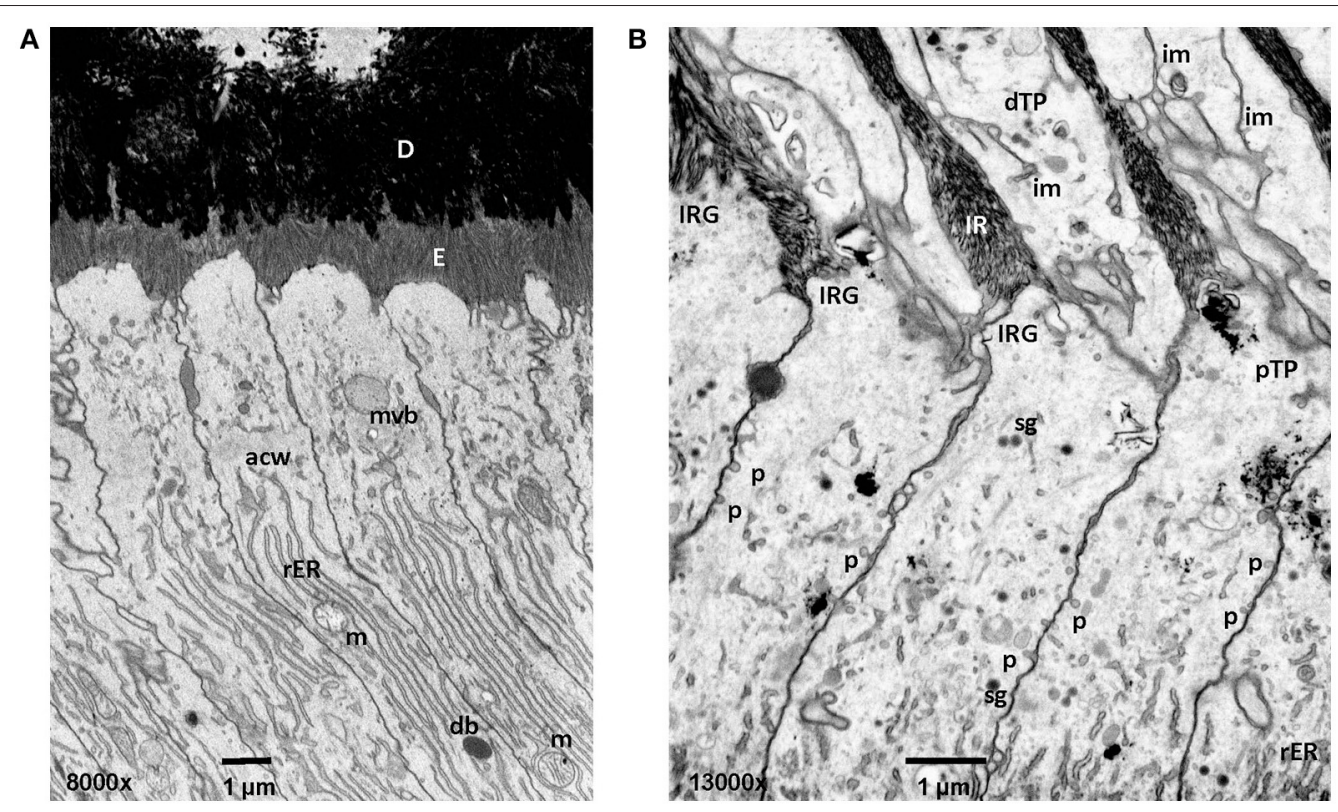

FIGURE 3 | Early and mid secretory stage ameloblasts in mandibular mouse incisors. All procedures involving animals were reviewed and approved by the IACUC committee at the University of Michigan and all relevant guidelines were followed. Handling of animals and tissues was followed according to protocols described earlier (Smith et al., 2016). (A) The Tomes' processes are not fully developed in early secretory stage ameloblasts. Enamel crystallite ribbons in the initial interrod layer are oriented perpendicular to dentin and the apical ameloblast membrane. (B) In mid secretory ameloblasts pinocytotic vesicles are observed along the non-secreting surface of the Tomes' process and laterally between adjacent ameloblasts below the level of the apical junctional complex. In the distal portion of the Tomes process membrane infoldings form a complex network and are in close relationship to vesicles. D, dentin; E, enamel; mvb, multivesicular body; acw, apical cell web; rER, rough endoplasmic reticulum; m, mitochondria; db, dense body (lysosome); im, membrane infolding; dTP, distal portion of Tomes' process; IRG, interrod growth site; pTP, proximal portion of Tomes' process; sg, secretory granule; $p$, pinocytotic vesicle.

a mechanism to communicate the status of the extracellular environment and the cells, endocytosis is a vehicle for executing cell homeostasis including uptake of nutrients, matrix- cell communication, changes in cell shape and polarity (Mills, 2007; Eaton and Martin-Belmonte, 2014; Villasenor et al., 2016). Beyond the homeostasis of a single cell, endocytosis is essential for the homeostasis of multicellular tissues, organs and communities (Mostov and Cardone, 1995; Mellman, 1996).

The prerequisite for the regulation of endocytosis is that cells are able to receive and respond to external signals (Pelkmans et al., 2005). The interaction can be modulated through different uptake mechanisms and through ligandreceptor binding, inducing specific cellular functions (Le Roy and Wrana, 2005). Identified uptake pathways include non-specific macropinocytosis and specific receptormediated/clathrin-mediated and caveolae/raft-mediated endocytosis (Racoosin and Swanson, 1992; Swanson and Watts, 1995; Mellman, 1996; Conner and Schmid, 2003). The interaction between receptor and ligand triggers a change in the conformation in the cytosolic tail that includes motifs for internalization (Dahlen et al., 2003; Pandey, 2009). These motifs are tyrosine or dileucine based and are critical for internalization efficiency and for routing the cargo to the intended designation (Collawn et al., 1993; Dahlen et al., 2003; Pandey, 2009).

\section{Clathrin-Mediated Endocytosis}

The most extensively described endocytosis pathway is clathrinmediated endocytosis. The generation of coated vesicles was discovered in mosquito oocytes (Roth and Porter, 1964). Each clathrin subunit consists of three large (heavy) and three small (light) polypeptide chains resembling a triskelion, a three-legged structure (Pearse, 1975, 1976). Clathrin molecules self-assemble into a 3-dimensional lattice supported by the heavy chains in the shape of a basket. The assembly and disassembly of clathrin around the vesicle is controlled by the clathrin light chains (Pearse, 1976). Clathrin uses adapter proteins (AP) to bind to membranes or cargo (Pearse et al., 2000; Sorkin, 2004). Clathrinmediated endocytosis regulates the internalization and recycling of receptors employed in cellular activities. Some examples are signal transduction, cell adhesion, cell proliferation, nutrient uptake and synaptic vesicle reformation (Polo and Di Fiore, 2006; Saheki and De Camilli, 2012; Antonescu et al., 2014).

Vesicles found in preameloblasts, Tomes' processes of secretory ameloblasts and maturation stage ameloblasts are either coated or non-coated (Smith, 1979; Ozawa et al., 1983; Sasaki, 1984a,b; Franklin et al., 1991; Uchida and Warshawsky, 1992). Compared to uncoated vesicles originating either from secretion or endocytosis, coated vesicles are inactive for the internalized vesicles via the clathrin-mediated pathway. Coated vesicles are described in electron micrographs of secretory stage ameloblasts with a size of $0.1-0.12 \mu \mathrm{m}$ in diameter 
(Reith and Cotty, 1967; Garant and Nalbandian, 1968). In presecretory ameloblasts, coated vesicles are found in the cytoplasmic protrusion that penetrate the basal lamina and facilitate its degradation (Katchburian and Burgess, 1983). In secretory stage ameloblasts, extracellular material is internalized by coated vesicles and tubulovesicular structures (Sasaki, 1984a). Coated vesicles have a tight relationship to tubules residing in the core of the Tomes' process (Uchida and Warshawsky, 1992). Tubules branch out from the core and are part of a network. In maturation stage ameloblasts, coated vesicles are found in ruffle-ended ameloblasts that are filled with fine granular material (Sasaki, 1984b). In contrast, smooth-ended ameloblasts contain only few coated vesicles (Kallenbach, 1980a; Sasaki, 1984b). The morphological difference in the apical membrane of maturation stage ameloblasts suggests that their function is dedicated to different processes with high resorptive activities associated with a ruffled border and low resorptive, but homeostasis activities with a smooth-ended border (Figure 2; Takano and Ozawa, 1980).

The endocytosis of amelogenin in enamel organ epithelium is proposed via clathrin dependent endocytosis involving the receptor proteins lysosome-associated membrane protein 1 (Lamp1) and cluster of differentiation 63 (CD63) (Shapiro et al., 2007; Lacruz et al., 2013a). Lamp1 and CD63 are transmembrane proteins routed between the membranes of the cell surface and lysosomes via endocytosis and via recycling pathways. Lamp1 and CD63 may interact with AP-2 clathrin AP for the uptake of clathrin-coated vesicles in ameloblasts (Lacruz et al., 2013a). The regulation of endocytosis may involve the microRNA miR-153 through interactions with Lamp1 and clathrin (Yin et al., 2017).

\section{Pinocytosis}

Fluid-phase endocytosis called pinocytosis can be distinguished by the size of the pinosomes as macropinocytosis and micropinocytosis. While macropinocytosis marks the uptake of fluid phase, micropinocytosis is associated with receptormediated and fluid-phase uptake.

Fluid phase endocytosis represents an uptake mechanism documented as occurring in ameloblasts. The process of fluid phase endocytosis trafficking of cargo can be demonstrated by supplying exogenously provided horseradish peroxidase (HRP) and observing the intracellular localization of HRP in cell organelles to which HRP is transported. For this technique, HRP is intravenously injected as a $5 \%$ solution and animals are sacrificed after 15-90 min (Sasaki, 1984c). During secretory stage, the apical terminal bars are not permeable for HRP (Kallenbach, 1980b). HRP accumulates at rod and interrod growth sites. The uptake of large quantities of HRP takes place at the Tomes' process and is subsequently trafficked to endosomes and lysosomes (Kallenbach, 1980b; Matsuo et al., 1986). In maturation stage ameloblasts, the apical and basal tight junctions open and close as ameloblasts modulate between ruffle-ended and smooth-ended forms and allow HRP to reach intercellular spaces between ameloblasts and close to the papillary layer (Sasaki et al., 1983a). HRP is rapidly internalized in large quantities and is carried forward in coated pits, vesicles, multivesicular bodies (MVB) and tubulovesicular structures
(Sasaki and Higashi, 1983; Sasaki et al., 1983b; Sasaki, 1984a,c). Accumulated HRP is incorporated from the cell membrane into the cytoplasm through pinosomes and pinocytotic coated vesicles (Sasaki, 1984a). The pinosomes then fuse to form large endocytic vesicles. HRP is accumulated in the endocytic vacuoles and MVB which serve as a carrier for HRP (Sasaki, 1984c). High magnification focused ion beam micrographs reveal pinocytotic activity at the lateral membranes of the proximal portion of the Tomes' Process (Figure 3). HRP can be followed from internalization through the endocytic compartment to the lysosomes where it is digested by lysosomes (Kallenbach, 1980b).

\section{Phagocytosis}

Phagocytosis describes the uptake of a solid particle $(>0.5$ $\mu \mathrm{m})$ by the cell to form an internal compartment known as a phagosome (Gordon, 2016). In unicellular eukaryotes, phagocytosis serves in the acquisition of nutrients. In mammalian cells, phagocytosis is a mechanism for immune cells, such as macrophages, neutrophils, and dendritic cells to remove pathogens, damaged cell organelles and dead cells. In contrast to pinocytosis endosomes, phagosomes can be as large as the phagocyte, depending on the size of the ingested particle. Phagocytosis is initiated by membrane protrusions (filopodia) in direction of the particle and through binding of the particle to cell surface receptors. Pathogen-associated molecular patterns, Fc regions of antibodies, complement molecules and apoptotic cells are recognized by cell surface receptors (Flannagan et al., 2012; Gordon, 2016). After ingestion of the particle the phagosome fuses with a lysosome where the particle is exposed to degradation and microbicidal action.

After completion of the secretory stage, ameloblasts go through a brief shift to enter the maturation stage. This shift is accompanied by notable changes in ameloblasts morphology from tall polarized cells with a Tomes' process to shorter polarized cells without an apical process. In rodent incisors, this change occurs within 19 hours (Smith and Warshawsky, 1977). About 25\% of transitional stage ameloblasts perish into cellular debris of varying size found between and below ameloblasts (Moe and Jessen, 1972). Cellular debris is distinct from ameloblasts with their dense cytoplasm surrounded by wide intercellular spaces between ameloblasts. It can cross intercellular spaces to the adjacent cell layer (stratum intermedium). Cells of the stratum intermedium form cytoplasmic processes to engulf ameloblast debris (Moe and Jessen, 1972). During the transition and maturation stages, macrophages are present in the forming papillary layer that are involved in the removal of cellular debris (Jessen and Moe, 1972; Nishikawa and Sasaki, 1996).

\section{ENDOCYTIC TRAFFICKING OF VESICLES}

Vesicles that originated by phagocytosis or pinocytosis contain cargo in the form of bound ligands or extracellular liquid phase material. The movement of vesicles within the cell to their destination compartment or organelle is called endocytic trafficking. Newly formed vesicles are first transported into early endosomes to sort them based on their content and to direct 
them to their destination. Endosomes can progress to lysosomes to degrade their content or fuse with the plasma membrane to return receptors and release the content to the environment. A group of proteins in the Ras superfamily of GTPases (Rab proteins) have been identified as the molecular machinery that regulates membrane trafficking pathways (Segev, 2001). They take part in vesicle formation, motility, docking, membrane remodeling and fusion (Segev, 2001).

\section{Ras Superfamily of GTPases}

Rab proteins constitute the largest branch of the Ras superfamily with over 70 members. They are small GTPases/GTP-binding proteins of $21-25 \mathrm{kDa}$ and localize to the cytosolic periphery of the membrane. As the predominant regulators of trafficking of endocytic vesicles, they control the un-coating, tethering, and membrane fusion and are executed by different types of Rabs (Hutagalung and Novick, 2011; Jena, 2011). The directionality of the vesicles is determined by the type of Rab protein localizing with the membrane of the endocytic organelle (Table 2, Figure 4; Hutagalung and Novick, 2011). Rab genes are highly conserved from yeast to human (Colicelli, 2004). Rab GTPases interact with the cytosolic aspect of the intracellular compartment to regulate and direct vesicles along different pathways. Through their effectors, Rab GTPases control vesicle formation, vesicle movement mediated by microfilaments, and membrane fusion (Hammer and Wu, 2002; Short et al., 2002).

In the enamel organ, a limited number of Rab GTPases have been investigated. Rab10 and Rab24 were localized to ameloblasts of the maturation stages and papillary cells (Lacruz et al., 2013a). Rab10 assists in the trafficking of vesicles from the Golgi apparatus to the basolateral membrane (Schuck et al., 2007). $\mathrm{Rab} 24$ is found in the endoplasmatic reticulum, cis-Golgi and late endosomes related to autophagy (Munafo and Colombo, 2002). In presecretory to secretory ameloblasts Rab23 was localized possibly negatively regulating sonic hedgehog signaling (Miletich et al., 2005).

\section{Endosomal Vesicles}

Endosomes are membrane-bound compartments inside of eukaryotic cells containing material that was internalized from the exterior of the cell. Their function is to sort and transport vesicles containing internalized solutes, receptors, lipids or pathogenic agents. Through their cargo, they also carry information from the extracellular compartment into the cell critical for cell morphology, maintenance and response to signals (Villasenor et al., 2016). Efficient sorting routes the vesicles to their destinations within the cells, such as the Golgi apparatus, lysosomes and plasma membrane. The two major sorting stations are the early and late endosomes (Mellman, 1996; Russell et al., 2006). Among the early endosomes, late endosomes, and lysosomes exists a dynamic and adaptable continuum with transient hybrid forms. An endosome fused with a lysosome is called an endolysosome. The endocytosis pathway is versatile because the organelles undergo continuous maturation, transformation, fusion, and fission (Huotari and Helenius, 2011). The following paragraphs describe the endocytic pathways of

TABLE 2 | Intracellular proteins in endocytic, transcytic, and exocytic pathways.

\begin{tabular}{|c|c|c|c|c|}
\hline Protein & Human genes & Intracellular localization & Function & References (cloning, localization, function) \\
\hline \multicolumn{5}{|l|}{ RAB PROTEINS } \\
\hline Rab1 & $R A B 1 A, R A B 1, Y P T 1$ & ER-Golgi intermediate & $\begin{array}{l}\text { Anterograde trafficking from ER } \\
\text { to Golgi }\end{array}$ & $\begin{array}{l}\text { Zahraoui et al., 1989; Tisdale et al., 1992; } \\
\text { Zerial and McBride, } 2001\end{array}$ \\
\hline Rab2 & $R A B 2 A, L H X, R A B 2$ & ER-Golgi intermediate & $\begin{array}{l}\text { Retrograde trafficking from Golgi } \\
\text { to ER }\end{array}$ & $\begin{array}{l}\text { Zahraoui et al., 1989; Chavrier et al., 1990; } \\
\text { Tisdale et al., } 1992\end{array}$ \\
\hline Rab4 & $R A B 4 A$ & EE and RE & $\begin{array}{l}\text { Trafficking from EE and RE to } \\
\text { plasma membrane }\end{array}$ & $\begin{array}{l}\text { Zahraoui et al., 1989; van der Sluijs et al., } \\
\text { 1992; Seachrist and Ferguson, } 2003\end{array}$ \\
\hline Rab5 & $R A B 5 A, R A B 5$ & Clathrin coated vesicles and EE & $\begin{array}{l}\text { Endocytic internalization and EE } \\
\text { fusion }\end{array}$ & $\begin{array}{l}\text { Zahraoui et al., 1989; Chavrier et al., 1990; } \\
\text { Somsel Rodman and Wandinger-Ness, } 2000\end{array}$ \\
\hline Rab7a & $R A B 7 A, P R O 2706$ & LE & $\begin{array}{l}\text { Trafficking from EE to LE and } \\
\text { from LE to lysosomes }\end{array}$ & $\begin{array}{l}\text { Chavrier et al., 1990; Harrison et al., 2003; } \\
\text { Guerra and Bucci, } 2016\end{array}$ \\
\hline Rab7b & $R A B 7 B, R A B 7$ & LE & Trafficking from LE to TGN & Surmacz et al., 2006; Progida et al., 2010 \\
\hline Rab8 & RAB8A, MEL, RAB8 & Median Golgi and TGN & $\begin{array}{l}\text { Trafficking from median Golgi and } \\
\text { TGN to basolateral membrane }\end{array}$ & $\begin{array}{l}\text { Huber et al., 1993; Chen and Wandinger-Ness, } \\
\text { 2001; Peranen, 2011 }\end{array}$ \\
\hline Rab9 & $R A B 9 A, R A B 9$ & LE & $\begin{array}{l}\text { Retrograde transport from LE to } \\
\text { trans-Golgi }\end{array}$ & $\begin{array}{l}\text { Lombardi et al., 1993; Soldati et al., 1995; } \\
\text { Davies et al., } 1997\end{array}$ \\
\hline Rab10 & RAB10 & Golgi & $\begin{array}{l}\text { Trafficking and recycling from } \\
\text { Golgi to basolateral membrane }\end{array}$ & $\begin{array}{l}\text { Chen et al., 1993; Bao et al., 1998; Schuck } \\
\text { et al., } 2007\end{array}$ \\
\hline Rab14 & $R A B 14, F B P$ & EE and Golgi & Transport from Golgi to EE & $\begin{array}{l}\text { Elferink et al., 1992; Junutula et al., 2004; } \\
\text { Proikas-Cezanne et al., } 2006\end{array}$ \\
\hline $\begin{array}{l}\text { Rab31 (alternate } \\
\text { name Rab22b) }\end{array}$ & RAB31 & EE and TGN & $\begin{array}{l}\text { Anterograde transport from TGN } \\
\text { to early endosomes }\end{array}$ & Rodriguez-Gabin et al., 2001; Ng et al., 2007 \\
\hline
\end{tabular}

$E R$, endoplasmatic reticulum; EE, early endosome; RE, recycling endosome; LE, late endosome; TGN, trans-Golgi network. 
vesicles following internalization from the extracellular matrix (Figure 4).

\section{Early Endosomes}

Early endosomes are the initial endocytic vesicle to accept incoming internalized molecules (Gruenberg et al., 1989). Their shapes vary from thin tubes ( $\sim 60 \mathrm{~nm}$ diameter) to large spheres ( $\sim 400 \mathrm{~nm}$ diameter). As membrane invaginations and scission events occur simultaneously on the endosome membrane, the shape of the endosomes underlies dynamic changes (Gruenberg, 2001). Proteins targeted for recycling may accumulate within tubular membranes. Early endosomes are a hub for sending vesicles off to late endosomes, recycling endosomes, vesicles from the Trans Golgi network or lysosomes. Internalized vesicles are assisted in their transport to and fusion with early endosomes by Rab5. Rab5 tethers to the membranes of cells and endosomes via a C-terminal hydrophobic isoprenoid moiety (Peter et al., 1992; Desnoyers et al., 1996; Shen and Seabra, 1996). In addition to controlling the origination of vesicles from the plasma membrane, vesicle Rab5 helps to recruit Rab7 as endosomes progress from early to late endosomes via fusion events (Gorvel et al., 1991; Huotari and Helenius, 2011). The fusion of endosomes is facilitated by effector proteins including early endosome antigen 1 (EEA1), rabenosyn5 and multiprotein complex C core vacuole/endosome tethering (CORVET) (Rubino et al., 2000; Balderhaar and Ungermann, 2013; Gautreau et al., 2014).

\section{Trans-Golgi Network and Recycling Endosomes}

The trans-Golgi network (TGN) is the site for sorting newly translated membrane and secretory proteins (Griffiths and Simons, 1986; Mellman and Warren, 2000). Several Rab proteins carry out the vesicle transport from the TGN to early endosomes or plasma membrane for release (Figure 4). Rab31 transports vesicles bidirectionally between the TGN and early endosomes (Rodriguez-Gabin et al., 2009). Vesicles with Rab1 and Rab2 are transported from the TGN to the endoplasmatic reticulum and vice versa, respectively (Plutner et al., 1991; Tisdale et al., 1992, 2004). Rab8 is recruited for the transport of vesicles destined to release proteins from the TGN to basolateral membranes (Huber et al., 1993). Vesicles arriving at the TGN from either the endoplasmatic reticulum or the late endosome are bound for secretion at the plasma membrane via Rab4 (van der Sluijs et al., 1992; Junutula et al., 2004).

Synthesis and secretion are major functions of ameloblasts during enamel formation. The morphology of ameloblasts changes greatly when they differentiate and begin appositional growth of the enamel layer thereby initiating the secretory stage. Secretory stage ameloblasts in rodent incisors, for example, have width to height dimensions of approximately 4-60 $\mu \mathrm{m}$ (1:15). The extreme extension of the ameloblasts facilitates the accommodation of a large number of pronounced cell organelles to synthesize and secrete enamel proteins and to support enamel mineralization. After transcription into mRNA in the nucleus and protein translation in the rough endoplasmatic reticulum, the synthesized enamel proteins progress through the centrally

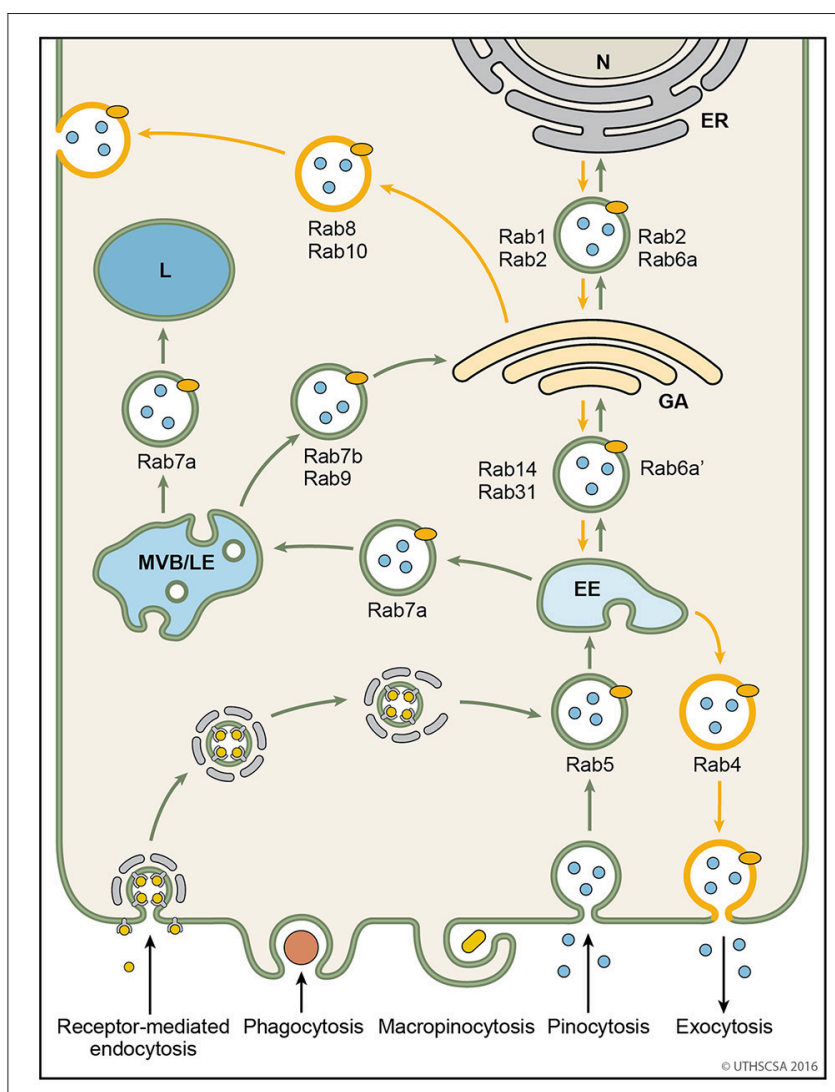

FIGURE 4 | Vesicular trafficking pathways during endocytosis. Schematic diagram showing the general pathways of internalized material. Molecules are taken up into vesicles via various types of endocytosis (receptor-mediated, phagocytosis, micropinocytosis, pinocytosis). Vesicles (coated and non-coated) fuse with EE, the first cellular sorting station, where the cargo is distributed to MVB/LE, GA or back to the plasma membrane (recycling pathway) via their respective Rab proteins. Cargo which is destined for degradation in lysosomes, is transported from EE to lysosomes via MVB/LE. At MVB/LE vesicles can still enter the recycling pathway via GA. Decreasing $\mathrm{pH}$ in the EE, MVB/LE, and lysosome are indicated by different shades of blue. EE, early endosome; ER, endoplasmatic reticulum; GA, Golgi apparatus; L, lysosome; MVB/LE, multivesicular body/late endosome; N, nucleus.

located and very large tubular-shaped Golgi apparatus for posttranslational modification and packaging into secretory granules. The supranuclear cytoplasm between nucleus and the Tomes' process is filled with rough endoplasmatic reticulum, Golgi apparatus cisternae, and vesicles, forming an intricate network of membranes in constant exchange of membrane and cargo (Garant and Nalbandian, 1968; Warshawsky, 1968; Sasaki, 1983a; Sasaki and Higashi, 1983). The Golgi cisternae are oriented perpendicular to the nucleus, following the long axis of the cell body. They occupy much of the supranuclear compartment between the nucleus and the microfilaments of the apical cell web with the dimension of $25 \times 1.5 \mu \mathrm{m}$, but do not penetrate into the Tomes' process (Kallenbach et al., 1963; Garant and Nalbandian, 1968). The saccular stacks of the Golgi apparatus adopt an openended, tubular structure and are polarized with shorter saccular stacks on the periphery and long flattened cisternae internally located (Garant and Nalbandian, 1968; Nanci et al., 1993). The 
endoplasmatic reticulum surrounds the Golgi apparatus in the periphery.

The number of vesicles shuttling between the rough endoplasmatic reticulum, the Golgi apparatus and the plasma membrane is large (Garant and Nalbandian, 1968). They accumulate in the Tomes' process close to the secretory face (Reith, 1967; Garant and Nalbandian, 1968). Vesicles with a dense content are, in average, of $0.8-0.16 \mu \mathrm{m}$ in diameter (Garant and Nalbandian, 1968; Warshawsky, 1968) and contain enamel proteins to be released at the plasma membrane (Uchida et al., 1991).

All secretory stage enamel proteins, amelogenin (Nanci et al., 1987a, 1989; Inage et al., 1989), enamelin (Uchida et al., 1991; Dohi et al., 1998), and ameloblastin (Lee et al., 1996; Murakami et al., 1997; Uchida et al., 1998) were found in the Golgi apparatus of ameloblasts. They have also been identified in secretory vesicles and at the secretory face of the Tomes' process (Nanci et al., 1989; Uchida et al., 1991). One of the commonalities of the enamel proteins as part of the secreted calcium-binding phosphoprotein cluster is that all members are phosphorylated on a conserved serine residue in a SXE motif of exon 3 (Kawasaki et al., 2004). The enzyme catalyzing the phosphorylation has been identified as Golgi-localized casein kinase, encoded by FAM20C (Tagliabracci et al., 2012), localized to the Golgi apparatus of ameloblasts (Wang et al., 2013). The phosphorylation of enamel proteins is essential as mutations lead to non-lethal Raine syndrome with hypoplastic amelogenesis imperfecta (Acevedo et al., 2015).

After the completion of the secretory stage, maturation stage ameloblasts reduced their height, and the Golgi apparatus reduces its dimensions (Nanci et al., 1993). Most of the enamel proteins synthesized during the secretory stage are greatly reduced in expression by maturation stage ameloblasts (Somogyi-Ganss et al., 2012). They start to produce and secrete the basement membrane proteins amelotin (Holcroft and Ganss, 2011) and ODAM (Iwasaki et al., 2005; Nishio et al., 2010; Dos Santos Neves et al., 2012), implicated in the mineralization of the enamel surface (Abbarin et al., 2015; Nakayama et al., 2015; Núñez et al., 2016).

\section{Late Endosomes}

Along the endocytic pathway, early endosomes mature into late endosomes (Huotari and Helenius, 2011). Late endosomes are a sorting center to direct cargo to the lysosome, Golgi apparatus or opposite plasma membrane (recycling, transcytosis). In the course of conversion from early to late endosomes, Rab5 is removed and replaced with Rab7 (Rink et al., 2005) which is controlled by the membrane protein complex SAND-1/Mon-1 and HOPS (homotypic fusion and protein sorting) (Rink et al., 2005; Peralta et al., 2010; Poteryaev et al., 2010; Plemel et al., 2011). The late endosome is recruited to the target lysosome and tethered onto the lysosomal membrane by HOPS accomplishing the fusion (Balderhaar and Ungermann, 2013). Late endosomes provide an intersection for arriving and leaving vesicles and have a size between 250 and 1,000 nm (Huotari and Helenius, 2011). Incoming vesicles bring information about the environmental conditions and nutrients for the cell. Outgoing vesicles can carry signals for protein synthesis, secretion, endocytosis, recycling, and autophagy. Fusion events with other endosomes and lysosomes are executed by Rab7. Once the endosome fuses with a lysosome, the vesicle content will be degraded and the endosomal pathway cannot be re-entered (Luzio et al., 2007). Endocytic vesicles contain acid hydrolases that operate in an acidic environment and are indicative for degradation (Yamashiro and Maxfield, 1987).

Molecular markers for late endosomes in ameloblasts have not been described. In electron microscopy images unique features of late endosomes can be identified in ameloblasts in secretory and maturation stages with intraluminal vesicles (Katchburian et al., 1967; Reith and Cotty, 1967; Garant and Nalbandian, 1968; Katchburian and Holt, 1969; Smith, 1979; Matsuo et al., 1986; Nanci et al., 1987a, 1993; Salama et al., 1989; Franklin et al., 1991; Uchida and Warshawsky, 1992). MVB originate from fusion with early endosomes and lysosomes and can release their content into the extracellular environment. They represent a type of late endosomes and are found during the entire life cycle of ameloblasts. MVB are first found in pre-secretory ameloblast associated with finger-like projections and the disruption of the basement membrane between odontoblasts and pre-ameloblasts (Reith, 1967; Nanci et al., 1989). In ameloblasts of the secretory stage, MVB reside in the supranuclear zone of the cell (Sasaki, 1983b). During the maturation stage, the resorptive activity at the ruffled border is intense. Large quantities of HRP labeled fluid-phase material are resorbed via pinosomes and delivered to MVB (Sasaki, 1984c). The number of MVB is greater in early maturation compared to late maturation stage (Salama et al., 1990a).

Multivesicular bodies (MVB) containing amelogenin protein have been found with immune gold labeling techniques in secretory-stage, smooth-ended, and ruffle-ended ameloblasts (Nanci et al., 1987a, 1993). However, immunolocalization studies do not answer the question whether the proteins had intracellular or extracellular origin.

\section{Lysosomes}

Lysosomes originate from late endosomes. The transition between these two organelles is continuous, often forming an endo-lysosome before it transforms into a secondary or dense lysosome (Luzio et al., 2007; Huotari and Helenius, 2011). Lysosomes are the cell's primary degradation center and the terminal station in the endocytic pathway. They contain the breakdown of proteins, polysaccharides, and lipids catalyzed by a wide array of lipases, proteases, and glycosidases in an acidic environment (Luzio et al., 2007; Huotari and Helenius, 2011; Xu and Ren, 2015). Lysosomes generate an acidic luminal $\mathrm{pH}$ to activate hydrolytic enzymes and degrade. Acidification is accomplished by proton transport into the lysosome lumen countered by chloride (Dell'Antone, 1979; Ohkuma et al., 1982; Nelson et al., 2000; Sun-Wada et al., 2004; Mindell, 2012). Among lysosomal hydrolases, cathepsins play a major role in peptide degradation. Cathepsins are classified into serine, aspartic and cysteine proteases referring to the amino acid residue in the catalytic center. Cathepsins A (also called human protective protein) and $G$ contain a serine residue in their active site (Kawamura et al., 1980; Rudenko et al., 1995; Hof et al., 1996), 
while cathepsins $\mathrm{D}$ and $\mathrm{E}$ have an aspartic acid residue in their active site (Shewale and Tang, 1984; Ostermann et al., 2004). Accordingly, cathepsins B, C (also known as dipeptidyl peptidase I), F, H, K, L, O, S, V, W, and X each feature a cysteine residue in the catalytic site (Turk et al., 2012). While cathepins B, H, $\mathrm{L}, \mathrm{C}, \mathrm{X}, \mathrm{F}, \mathrm{O}$, and $\mathrm{V}$ are ubiquitously expressed (Turk et al., 2012), cathepsins $K, W$, and $S$ are only found in specific tissues. Cathepsin $\mathrm{K}$, for example is highly expressed in osteoclasts, and in many epithelial cells (Drake et al., 1996; Buhling et al., 1999; Salminen-Mankonen et al., 2007).

In enamel formation lysosomes are found in ameloblasts at presecretory, secretory and maturation stages (Katchburian and Burgess, 1983; Nanci et al., 1987a,b). Lysosomal activity for acid phosphatase has been demonstrated in preameloblasts, secretory and maturation stage ameloblasts located in granules within the center of the supranuclear region and in the Tomes' process (Katchburian et al., 1967). In preameloblasts, the target of the resorptive function is the basal lamina facing odontoblasts (Katchburian and Burgess, 1983; Uchida et al., 1989). During secretory and maturation stages, enamel proteins are removed from the matrix through resorption by ameloblasts (Reith and Cotty, 1967; Nanci et al., 1987a,b; Salama et al., 1990a). Large lysosomes can have smooth or rough surfaces in maturation stage ameloblasts (Nanci et al., 1993). The shape of lysosomes is described as spherical and elongated, tubular with sizes ranging from 80 to $140 \mathrm{~nm}$ in length (Salama et al., 1989).

Lysosomal enzymes present in ameloblasts include acid phosphatase, $\beta$-glucoronidase, and leucyl-naphthylamidase (Beynon, 1972). The distinction between pale and dark lysosomes was derived from the electron density of deposits observed with electron microscopy. Pale lysosomes stain inconsistently with inorganic trimetaphosphatase and acid phosphatase. In contrast, dark lysosomes are reliably positive for inorganic trimetaphosphatase (Nanci et al., 1987b). Dark lysosomes contain less protein than pale lysosomes as they are secondary lysosomes with ongoing protein degradation (Nanci et al., 1987a). Ruffle-ended ameloblasts show more endocytic activity than smooth-ended ameloblasts (Nanci et al., 1987b). Interestingly, the lysosomal activity of ameloblasts is higher during secretory stage compared to maturation stages (Table 1). Among the enamel proteins, amelogenin localizes to lysosomes (Nanci et al., 1987b; Inage et al., 1989). Whether enamelin localizes to lysosomes is not clear since the antibody was raised against a protein species of $50-70 \mathrm{kDa}$ potentially containing enamelin and/or ameloblastin (Inage et al., 1989). Much of the degradative effort in lysosomes is associated with cathepsin B, D, F, H, K, L, O, S, and Z expressed by maturation stage ameloblasts (Tye et al., 2009).

\section{PERSPECTIVES AND FUTURE DIRECTIONS}

Enamel mineralizes and matures as a result of a balance between synthesis, deposition, degradation and internalization. The homeostasis between ameloblasts and matrix is critical for proper enamel formation. The intracellular transport of vesicles is important for polarization of epithelial cells, serving as a mechanism to regulate differentiation (Bryant and Mostov, 2008; Butler and Wallingford, 2017). Endocytosis is a fundamental cell function executed during all stages of the ameloblast life cycle to create the most mineralized hard tissue. Since the enamel matrix represents a secluded compartment surrounded by dentin and ameloblasts (Bronckers, 2016), ameloblasts are granted full control of enamel formation. No other cell type has direct access to the enamel matrix. As a result, ameloblasts closely monitor the transport of ions and proteins across the membrane, necessary to control crystal growth. Endocytosis may be a mechanism for communicating changes in the maturing enamel to the ameloblasts. Each of the various stages of amelogenesis has specific criteria that need to be fulfilled to allow cells to advance to the next stage. Disruption of the completion of a stage results in severe cell pathology as caused by absence of any of the enamel proteins (amelogenin, ameloblastin, enamelin), matrix metalloproteinase 20 or kallikrein4 (Fukumoto et al., 2004; Simmer et al., 2009; Bartlett et al., 2011; Hu et al., 2014, 2016). The inability to cleave the enamel proteins is associated with hypomineralized enamel and matrix-retained proteins (Simmer et al., 2009; Bartlett et al., 2011), allowing the conclusion that cleavage and degradation of enamel proteins are a prerequisite for effective endocytosis. Appropriate feedback to ameloblasts is required to maintain ameloblast function (Chun et al., 2010).

Aside from releasing and internalizing vesicle content, the vesicle membrane may supply or reduce the plasma membrane surface when vesicles fuse with the membrane or are pinched off from the membrane. Thereby, the shape and size of the cell may be modified. During the life cycle of an ameloblast, the cell undergoes significant changes in cell shape. During the development of the Tomes' process in preameloblasts, the membrane surface is enlarged which could be supplied by secretory vesicles. During this event, secretion may dominate over endocytosis. Once the Tomes process has been established in secretory stage ameloblasts, secretion and endocytosis may take place in equilibrium. Given the intense protein synthesis activity of secretory ameloblasts, a mechanism is needed to attain homeostasis of membrane surface and the overall cell shape. The three-dimensional shape of the Tomes' process coordinates enamel ribbons in the characteristic rod and interrod enamel. The forming interrod enamel completely surrounds the protruded distal portion of the Tomes' process like prongs. The interrod enamel originates from the proximal portions of the Tomes' process. If ameloblasts were separated from the forming enamel, a cavity in which the Tomes' process resides would become visible from a baso-apical direction. The interrod enamel would be elevated and form a rim surrounding a cavity in the shape of the Tomes' process. The interrod is partially mineralized, and therefore may restrict the size and shape the Tomes' process is able to adopt. When a secretory vesicle undergoes fusion with the surface membrane of a cell, the vesicle experiences a gain in membrane and increases the overall surface of the cell. For the Tomes' process, a gain in membrane from secretory vesicles would alter and enlarge the shape of the Tomes' process. However, being encased by rigid rod and interrod enamel, an enlarged Tomes' process would collide with 
enamel ribbons. Endocytosis, on the other hand, removes plasma membrane from the cell surface when vesicles are pinched off and trim the contour of the Tomes' process. Invaginations of the plasma membrane of the Tomes' process present an elegant solution to offer surface membrane, but because it is shifted internally, variability in the shape due to membrane fusion from secretory or endocytic vesicles is bypassed. As a result, the surface membrane and the shape of the Tomes' process remain largely unaltered. When the ameloblast progresses from secretory stage to transition stage and maturation stages, the cell's dimensions are reduced and the Tomes' process is dismantled. A preference of endocytosis events would facilitate a reduction in cell surface membrane. Ruffle-ended maturation stage ameloblasts display high activity in endocytosis. Throughout amelogenesis, secretion and endocytosis are highly prominent operations in ameloblasts that may participate in the control of the cell membrane surface available to form and disassemble cell appendages and infoldings and invaginations.

During their life cycle, ameloblasts adopt many different morphologically distinct appearances as preameloblast, secretory ameloblast, transition stage ameloblast, ruffle-ended ameloblast, smooth-ended ameloblast, and reduced enamel epithelium. The sites of endocytosis on the ameloblast membrane are different in each stage. Small processes are protruded into the basal lamina in preameloblasts. The Tomes' process of the secretory ameloblast is a very large projection from the apical membrane. The infoldings of the membrane distal portion form inwards in the Tomes' process. The ruffled border of maturation stage ameloblasts is formed much differently from the secretory stage infoldings associated with rod and interrod growth sites. They sink into the supranuclear cytoplasmic mass. The stagespecific mechanisms and pathways of endocytosis in ameloblasts are not well defined. While strong evidence is available

\section{REFERENCES}

Abbarin, N., San Miguel, S., Holcroft, J., Iwasaki, K., and Ganss, B. (2015). The enamel protein amelotin is a promoter of hydroxyapatite mineralization. $J$. Bone Miner. Res. 30, 775-785. doi: 10.1002/jbmr.2411

Acevedo, A. C., Poulter, J. A., Alves, P. G., de Lima, C. L., Castro, L. C., Yamaguti, P. M., et al. (2015). Variability of systemic and oro-dental phenotype in two families with non-lethal Raine syndrome with FAM20C mutations. BMC Med. Genet. 16:8. doi: 10.1186/s12881-015-0154-5

Antonescu, C. N., McGraw, T. E., and Klip, A. (2014). Reciprocal regulation of endocytosis and metabolism. Cold Spring Harb. Perspect. Biol. 6:a016964. doi: 10.1101/cshperspect.a016964

Balderhaar, H. J., and Ungermann, C. (2013). CORVET and HOPS tethering complexes-coordinators of endosome and lysosome fusion. J. Cell Sci. 126(Pt 6), 1307-1316. doi: 10.1242/jcs. 107805

Bao, S., Zhu, J., and Garvey, W. T. (1998). Cloning of Rab GTPases expressed in human skeletal muscle: studies in insulin-resistant subjects. Horm. Metab. Res. 30, 656-662. doi: 10.1055/s-2007-978953

Bartlett, J. D. (2013). Dental enamel development: proteinases and their enamel matrix substrates. SRN Dent. 2013:684607. doi: 10.1155/2013/684607

Bartlett, J. D., Skobe, Z., Nanci, A., and Smith, C. E. (2011). Matrix metalloproteinase 20 promotes a smooth enamel surface, a strong dentino-enamel junction, and a decussating enamel rod pattern. Eur. J. Oral Sci. 119, 199-205. doi: 10.1111/j.1600-0722.2011. 00864.x to document vesicles generated during endocytosis, so far, only clathrin-mediated endocytosis and pinocytosis have been identified in ameloblasts as internalization routes. Lipid rafts or caveolae-mediated endocytosis as a clathrin independent form of endocytosis has not been described in ameloblasts. Future directions in understanding endocytosis in ameloblasts should address the feedback mechanisms, differences in endocytosis types depending on the vesicle origin from the infolding of the Tomes' process vs. ruffled border vs. smooth-ended border vs. lateral membrane and the trafficking of endosomes.

\section{AUTHOR CONTRIBUTIONS}

$\mathrm{CP}$ and YC drafted the manuscript with help from CS. JH, JS, and CS planned experiments for Figure 3. YH and CS performed experiments for Figure 3. All authors contributed to the manuscript and approved it.

\section{FUNDING}

This work was supported by T32DE014318 (CP), K08DE022800 (YC), R21DE025758 (YC), R01DE026769 (YC), and R01DE015846 (JH) from the National Institute of Dental and Craniofacial Research and UL1TR001120 from the National Center for Advancing Translational Sciences. The authors are responsible for the content. It does not necessarily represent the official views of the National Institutes of Health.

\section{ACKNOWLEDGMENTS}

The authors thank Susan Simon, Medical Illustrator in Creative Media Services, University of Texas Health Science Center at San Antonio, for designing Figures 2 and 4.
Beynon, A. D. (1972). Enzymes in enamel maturation. Proc. R. Soc. Med. 65, 911-912.

Bronckers, A. L. (2016). Ion transport by ameloblasts during amelogenesis. J. Dent. Res. 96, 243-253. doi: 10.1177/0022034516681768

Bryant, D. M., and Mostov, K. E. (2008). From cells to organs:building polarized tissue. Nat. Rev. Mol. Cell Biol. 9, 887-901. doi: 10.1038/nrm2523

Buhling, F., Gerber, A., Hackel, C., Kruger, S., Kohnlein, T., Bromme, D., et al. (1999). Expression of cathepsin K in lung epithelial cells. Am. J. Respir. Cell Mol. Biol. 20, 612-619. doi: 10.1165/ajrcmb.20.4.3405

Butler, M. T., and Wallingford, J. B. (2017). Planar cell polarity in development and disease. Nat. Rev. Mol. Cell Biol. 18, 375-388. doi: 10.1038/nrm.2017.11

Chavrier, P., Parton, R. G., Hauri, H. P., Simons, K., and Zerial, M. (1990). Localization of low molecular weight GTP binding proteins to exocytic and endocytic compartments. Cell 62, 317-329. doi: 10.1016/0092-8674(90)90369-P

Chen, W., and Wandinger-Ness, A. (2001). Expression and functional analyses of Rab8 and Rab1la in exocytic transport from trans-Golgi network. Meth. Enzymol. 329, 165-175. doi: 10.1016/S0076-6879(01)29077-6

Chen, Y. T., Holcomb, C., and Moore, H. P. (1993). Expression and localization of two low molecular weight GTP-binding proteins, Rab8 and Rab10, by epitope tag. Proc. Natl. Acad. Sci. U.S.A. 90, 6508-6512. doi: 10.1073/pnas.90.14.6508

Chun, Y.-H. P., Lu, Y., Hu, Y., Krebsbach, P. H., Yamada, Y., Hu, J. C.-C., Simmer, J. P. et al. (2010). Transgenic rescue of enamel phenotype in ambn null mice. J. Dent. Res. 89, 1414-1420. doi: 10.1177/00220345103 79223 
Colicelli, J. (2004). Human RAS superfamily proteins and related GTPases. Sci. STKE 250:RE13. doi: 10.1126/stke.2502004re13

Collawn, J. F., Lai, A., Domingo, D., Fitch, M., Hatton, S., and Trowbridge, I. S. (1993). YTRF is the conserved internalization signal of the transferrin receptor, and a second YTRF signal at position 31-34 enhances endocytosis. J. Biol. Chem. 268, 21686-21692.

Conner, S. D., and Schmid, S. L. (2003). Regulated portals of entry into the cell. Nature 422, 37-44. doi: 10.1038/nature01451

Dahlen, D. D., Broudy, V. C., and Drachman, J. G. (2003). Internalization of the thrombopoietin receptor is regulated by 2 cytoplasmic motifs. Blood 102, 102-108. doi: 10.1182/blood-2002-11-3468

Davies, J. P., Cotter, P. D., and Ioannou, Y. A. (1997). Cloning and mapping of human Rab7 and Rab9 cDNA sequences and identification of a Rab9 pseudogene. Genomics 41, 131-134. doi: 10.1006/geno.1997.4644

Dell'Antone, P. (1979). Evidence for an ATP-driven "proton pump" in rat liver lysosomes by basic dyes uptake. Biochem. Biophys. Res. Commun. 86, 180-189. doi: 10.1016/0006-291X(79)90398-X

Desnoyers, L., Anant, J. S., and Seabra, M. C. (1996). Geranylgeranylation of Rab proteins. Biochem. Soc. Trans. 24, 699-703. doi: 10.1042/bst0240699

Dohi, N., Murakami, C., Tanabe, T., Yamakoshi, Y., Fukae, M., Yamamoto, Y., et al. (1998). Immunocytochemical and immunochemical study of enamelins, using antibodies against porcine $89-\mathrm{kDa}$ enamelin and its $\mathrm{N}$-terminal synthetic peptide, in porcine tooth germs. Cell Tissue Res. 293, 313-325. doi: $10.1007 / \mathrm{s} 004410051123$

Dos Santos Neves, J., Wazen, R. M., Kuroda, S., Francis Zalzal, S., Moffatt, P., and Nanci, A. (2012). Odontogenic ameloblast-associated and amelotin are novel basal lamina components. Histochem. Cell Biol. 137, 329-338. doi: 10.1007/s00418-011-0901-4

Drake, F. H., Dodds, R. A., James, I. E., Connor, J. R., Debouck, C., Richardson, S., et al. (1996). but not cathepsins B, L, or S, is abundantly expressed in human osteoclasts. J. Biol. Chem. 271, 12511-12516. doi: 10.1074/jbc.271.21. 12511

Eaton, S., and Martin-Belmonte, F. (2014). Cargo sorting in the endocytic pathway: a key regulator of cell polarity and tissue dynamics. Cold Spring Harb. Perspect. Biol. 6:a016899. doi: 10.1101/cshperspect.a016899

Elferink, L. A., Anzai, K., and Scheller, R. H. (1992). rab15, a novel low molecular weight GTP-binding protein specifically expressed in rat brain. J. Biol. Chem. 267, 5768-5775.

Fincham, A. G., Moradian-Oldak, J., Diekwisch, T. G., Lyaruu, D. M., Wright, J. T., Bringas, P. Jr., et al. (1995). Evidence for amelogenin "nanospheres" as functional components of secretory-stage enamel matrix. J. Struct. Biol. 115, 50-59. doi: 10.1006/jsbi.1995.1029

Flannagan, R. S., Jaumouille, V., and Grinstein, S. (2012). The cell biology of phagocytosis. Annu. Rev. Pathol. 7, 61-98. doi: 10.1146/annurev-pathol-011811-132445

Franklin, D. L., Severs, N. J., and Katchburian, E. (1991). Development of the distal end and Tomes' processes of ameloblasts observed by freeze-fracture and ultrathin section electron microscopy. J. Anat. 174, 103-114.

Fukae, M., Tanabe, T., Uchida, T., Lee, S. K., Ryu, O. H., Murakami, C., et al. (1998). Enamelysin (matrix metalloproteinase-20): localization in the developing tooth and effects of $\mathrm{pH}$ and calcium on amelogenin hydrolysis. J. Dent. Res. 77, 1580-1588. doi: 10.1177/00220345980770080501

Fukumoto, S., Kiba, T., Hall, B., Iehara, N., Nakamura, T., Longenecker, G., et al. (2004). Ameloblastin is a cell adhesion molecule required for maintaining the differentiation state of ameloblasts. J. Cell Biol. 167, 973-983. doi: $10.1083 /$ jcb. 200409077

Garant, P. R., and Nalbandian, J. (1968). Observations on the ultrastructure of ameloblasts with special reference to the golgi complex and related components. J. Ultrastruct. Res. 23, 427-443. doi: 10.1016/S0022-5320(68)80108-X

Gautreau, A., Oguievetskaia, K., and Ungermann, C. (2014). Function and regulation of the endosomal fusion and fission machineries. Cold Spring Harb Perspect Biol. 6:a016832. doi: 10.1101/cshperspect.a016832

Gordon, S. (2016). Phagocytosis: a immunobiologic process. Cell 44, 463-475. doi: 10.1016/j.immuni.2016.02.026

Gorvel, J. P., Chavrier, P., Zerial, M., and Gruenberg, J. (1991). rab5 controls early endosome fusion in vitro. Cell 64, 915-925. doi: 10.1016/0092-8674(91)90316-Q
Griffiths, G., and Simons, K. (1986). The trans Golgi network: sorting at the exit site of the Golgi complex. Science 234, 438-443. doi: 10.1126/science.2945253

Gruenberg, J. (2001). The endocytic pathway: a mosaic of domains. Nat. Rev. Mol. Cell Biol. 2, 721-730. doi: 10.1038/35096054

Gruenberg, J., Griffiths, G., and Howell, K. E. (1989). Characterization of the early endosome and putative endocytic carrier vesicles in vivo and with an assay of vesicle fusion in vitro. J. Cell Biol. 108, 1301-1316. doi: 10.1083/jcb.108.4.1301

Guerra, F., and Bucci, C. (2016). Multiple roles of the small GTPase Rab7. Cells 5:E34. doi: 10.3390/cells5030034

Hammer, J. A. III, and Wu, X. S. (2002). Rabs grab motors: defining the connections between Rab GTPases and motor proteins. Curr. Opin. Cell Biol. 14, 69-75. doi: 10.1016/S0955-0674(01)00296-4

Harrison, R. E., Bucci, C., Vieira, O. V., Schroer, T. A., and Grinstein, S. (2003). Phagosomes fuse with late endosomes and/or lysosomes by extension of membrane protrusions along microtubules: role of Rab7 and RILP. Mol. Cell. Biol. 23, 6494-6506. doi: 10.1128/MCB.23.18.6494-650 6.2003

Hof, P., Mayr, I., Huber, R., Korzus, E., Potempa, J., Travis, J., et al. (1996). The 1.8 A crystal structure of human cathepsin $\mathrm{G}$ in complex with Suc-Val-Pro-PheP$(\mathrm{OPh}) 2$ : a Janus-faced proteinase with two opposite specificities. EMBO J. 15, 5481-5491.

Holcroft, J., and Ganss, B. (2011). Identification of amelotin- and ODAMinteracting enamel matrix proteins using the yeast two-hybrid system. Eur. J. Oral Sci. 119(Suppl. 1), 301-306. doi: 10.1111/j.1600-0722.2011.00870.x

Hu, J. C., Hu, Y., Lu, Y., Smith, C. E., Lertlam, R., Wright, J. T., et al. (2014). Enamelin is critical for ameloblast intergity and enamel ultrastructure formation. PLoS ONE 9:e89303. doi: 10.1371/journal.pone.0089303

Huber, L. A., Pimplikar, S., Parton, R. G., Virta, H., Zerial, M., and Simons, K. (1993). Rab8, a small GTPase involved in vesicular traffic between the TGN and the basolateral plasma membrane. J. Cell Biol. 123, 35-45. doi: $10.1083 /$ jcb.123.1.35

Huotari, J., and Helenius, A. (2011). Endosome maturation. EMBO J. 30, 3481-3500. doi: 10.1038/emboj.2011.286

Hutagalung, A. H., and Novick, P. J. (2011). Role of Rab GTPases in membrane traffic and cell physiology. Physiol. Rev. 91, 119-149. doi: 10.1152/physrev.00059.2009

Hu, Y., Smith, C. E., Cai, Z., Donnelly, L. A., Yang, J., Hu, J. C., et al. (2016). Enamel ribbons, surface nodules, and octacalcium phosphate in C57BL/6 Amelx $^{-/-}$mice and Amelx ${ }^{+/-}$lyonization. Mol. Genet. Genomic Med. 4, 641-661. doi: $10.1002 / \mathrm{mgg} 3.252$

Inage, T., Shimokawa, H., Teranishi, Y., Iwase, T., Toda, Y., and Moro, I. (1989). Immunocytochemical demonstration of amelogenins and enamelins secreted by ameloblasts during the secretory and maturation stages. Arch. Histol. Cytol. 52, 213-229. doi: 10.1679/aohc.52.213

Iwasaki, K., Bajenova, E., Somogyi-Ganss, E., Miller, M., Nguyen, V., Nourkeyhani, H., et al. (2005). Amelotin-a novel secreted, ameloblastspecific protein. J. Dent. Res. 84, 1127-1132. doi: 10.1177/154405910508 401207

Jena, B. P. (2011). Role of SNAREs in membrane fusion. Adv. Exp. Med. Biol. 713, 13-32. doi: 10.1007/978-94-007-0763-4_3

Jessen, H., and Moe, H. (1972). The fine structure of macrophages in the enamel organ, with special reference to the microtubular system. Z. Zellforsch. Microsk. Anat. 126, 466-482. doi: 10.1007/BF00306907

Junutula, J. R., De Maziere, A. M., Peden, A. A., Ervin, K. E., Advani, R. J., van Dijk, S. M., et al. (2004). Rab14 is involved in membrane trafficking between the Golgi complex and endosomes. Mol. Biol. Cell 15, 2218-2229. doi: 10.1091/mbc.E03-10-0777

Kallenbach, E. (1973). The fine structure of Tomes' process of rat incisor ameloblasts and its relationship to the elaboration of enamel. Tissue Cell 5, 501-524. doi: 10.1016/S0040-8166(73)80041-2

Kallenbach, E. (1974). Fine structure of rat incisor ameloblasts in transition between enamel secretion and maturation stages. Tissue Cell 6, 173-190. doi: 10.1016/0040-8166(74)90030-5

Kallenbach, E. (1976). Fine structure of differentiating ameloblasts in the kitten. Am. J. Anat. 145, 283-318. doi: 10.1002/aja.1001450302

Kallenbach, E. (1980a). Access of horseradish peroxidase (HRP) to the extracellular spaces of the maturation zone of the rat incisor enamel organ. Tissue Cell 12, 165-174. doi: 10.1016/0040-8166(80)90059-2 
Kallenbach, E. (1980b). Fate of horseradish peroxidase in the secretion zone of the rat incisor enamel organ. Tissue Cell 12, 491-501. doi: 10.1016/0040-8166(80)90038-5

Kallenbach, E., Sandborn, E., and Warshawsky, H. (1963). The Golgi apparatus of the ameloblast of the rat at the stage of enamel matrix formation. J. Cell Biol. 16, 629-632. doi: 10.1083/jcb.16.3.629

Katchburian, E., and Burgess, A. M. (1983). Lysosomes and removal of the basal lamina of ameloblasts in early stages of odontogenesis. Cell Biol. Int. Rep. 7, 407-415. doi: 10.1016/0309-1651(83)90129-7

Katchburian, E., and Holt, S. J. (1969). Role of lysosomes in amelogenesis. Nature 223, 1367-1368. doi: 10.1038/2231367a0

Katchburian, E., Katchburian, A. V., and Pearse, A. G. E. (1967). Histochemistry of lysosomal enzymes in developing teeth of albino rats. J. Anat. 101, 783-792.

Kawamura, Y., Matoba, T., and Doi, E. (1980). Subunit structure of pig kidney cathepsin. J. Biochem. A. 88, 1559-1561.

Kawasaki, K., Suzuki, T., and Weiss, K. M. (2004). Genetic basis for the evolution of vertebrate mineralized tissue. Proc. Natl. Acad. Sci. U.S.A. 101, 11356-11361. doi: 10.1073/pnas.0404279101

Kim, S., Inoue, S., and Akisaka, T. (1994). Ultrastructure of quick-frozen secertory ameloblasts of the rat milar tooth. Tissue Cell 26, 29-41. doi: 10.1016/0040-8166(94)90081-7

Lacruz, R. S., Brookes, S. J., Wen, X., Jimenez, J. M., Vikman, S., Hu, P., et al. (2013a). Adaptor protein complex 2-mediated, clathrin-dependent endocytosis, and related gene activities, are a prominent feature during maturation stage amelogenesis. J. Bone Miner. Res. 28, 672-687. doi: $10.1002 /$ jbmr.1779

Lacruz, R. S., Smith, C. E., Kurtz, I., Hubbard, M. J., and Paine, M. L. (2013b). New paradigms on the transport functions of maturation-stage ameloblasts. J. Dent. Res. 92, 122-129. doi: 10.1177/0022034512470954

Lee, S. K., Krebsbach, P. H., Matsuki, Y., Nanci, A., Yamada, K. M., and Yamada, Y. (1996). Ameloblastin expression in rat incisors and human tooth germs. Int. J. Dev. Biol. 40, 1141-1150.

Le Roy, C., and Wrana, J. L. (2005). Clathrin- and non-clathrin-mediated endocytic regulation of cell signalling. Nat. Rev. Mol. Cell Biol. 6, 112-126. doi: $10.1038 / \mathrm{nrm} 1571$

Lombardi, D., Soldati, T., Riederer, M. A., Goda, Y., Zerial, M., and Pfeffer, S. R. (1993). Rab9 functions in transport between late endosomes and the trans Golgi network. EMBO J. 12, 677-682.

Luzio, J. P., Pryor, P. R., and Bright, N. A. (2007). Lysosomes: fusion and function. Nat. Rev. Mol. Cell Biol. 8, 622-632. doi: 10.1038/nrm2217

Matsuo, S., Yamamoto, K., Nishikawa, S., Ichikawa, H., Wakisaka, S., Takano, Y., et al. (1986). Influence of colchicine on the distribution of horseradish peroxidase in the secretory ameloblast layer in vitro. Anat. Rec. 216, 10-18. doi: 10.1002/ar.1092160103

Mellman, I. (1996). Endocytosis and molecular sorting. Annu. Rev. Cell Dev. Biol. 12, 575-625. doi: 10.1146/annurev.cellbio.12.1.575

Mellman, I., and Warren, G. (2000). The road taken: past and future foundations of membrane traffic. Cell 100, 99-112. doi: 10.1016/S0092-8674(00)81687-6

Miletich, I., Cobourne, M. T., Abdeen, M., and Sharpe, P. T. (2005). Expression of the Hedgehog antagonists Rab23 and Slimb/beta TrCP during mouse tooth development. Arch. Oral Biol. 50, 147-151. doi: 10.1016/j.archoralbio.2004.09.006

Mills, I. G. (2007). The interplay between clathrin-coated vesicles and cell signalling. Semin. Cell Dev. Biol. 18, 459-470. doi: 10.1016/j.semcdb.2007.07.001

Mindell, J. A. (2012). Lysosomal acidification mechanisms. Annu. Rev. Physiol. 74, 69-86. doi: 10.1146/annurev-physiol-012110-142317

Moe, H., and Jessen, H. (1972). Phagocytosis and elimination of amelocyte debris by stratum intermedium cells in the trasitional zone of the enamel organ of the rat incisor. Z. Zellforsch. Mikrosk. Anat. 131, 63-75. doi: 10.1007/BF00307201

Mostov, K. E., and Cardone, M. H. (1995). Regulation of protein traffic in polarized cells. Bioessays 17, 129-138. doi: 10.1002/bies.950170208

Munafo, D. B., and Colombo, M. I. (2002). Induction of autophagy causes dramatic changes in the subcellular distribution of GFP-Rab24. Traffic 3, 472-482. doi: 10.1034/j.1600-0854.2002.30704.x

Murakami, C., Dohi, N., Fukae, M., Tanabe, T., Yamakoshi, Y., Wakida, K., et al. (1997). Immunochemical and immunohistochemical study of the 27- and
29-kDa calcium-binding proteins and related proteins in the porcine tooth germ. Histochem. Cell Biol. 107, 485-494. doi: 10.1007/s004180050136

Nagano, T., Kakegawa, A., Yamakoshi, Y., Tsuchiya, S., Hu, J. C., Gomi, K., et al. (2009). Mmp-20 and Klk4 cleavage site preferences for amelogenin sequences. J. Dent. Res. 88, 823-828. doi: 10.1177/0022034509342694

Nakayama, Y., Holcroft, J., and Ganss, B. (2015). Enamel hypomineralization and structural defects in amelotin-deficient mice. J. Dent. Res. 94, 697-705. doi: 10.1177/0022034514566214

Nanci, A., Ahluwalia, J. P., Pompura, J. R., and Smith, C. E. (1989). Biosynthesis and secretion of enamel proteins in the rat incisor. Anat. Rec. 224, 277-291. doi: 10.1002/ar.1092240218

Nanci, A., Bendayan, M., and Slavkin, H. C. (1985). Enamel protein biosynthesis and secretion in mouse incisor secretory ameloblasts as revealed by highresolution immunocytochemistry. J. Histochem. Cytochem. 33, 1153-1160. doi: $10.1177 / 33.11 .4056379$

Nanci, A., Fortin, M., and Ghitescu, L. (1996). Endocytotic functions of ameloblasts and odontoblasts: immunocytochemical and tracer studies on the uptake of plasma proteins. Anat. Rec. 245, 219-234. doi: 10.1002/(SICI)1097-0185(199606)245:2<219::AID-AR9>3.0.CO;2-R

Nanci, A., Slavkin, H. C., and Smith, C. E. (1987a). Application of high resolution immunocytochemistry to the study of the secretory, resorptive and degradative functions of ameloblasts. Adv. Dent. Res. 1, 148-161. doi: 10.1177/08959374870010020301

Nanci, A., Slavkin, H. C., and Smith, C. E. (1987b). Immunocytochemical and radioautographic evidence for secretion and intracellular degradation of enamel proteins by ameloblasts during the maturation stage of amelogenesis in rat incisors. Anat. Rec. 217, 107-123. doi: 10.1002/ar.1092170202

Nanci, A., Uchida, T., and Warshawsky, H. (1987c). The effects of vinblastine on the secretory ameloblasts: an ultrastructural, cytochemical, and immunocytochemical study in the rat incisor. Anat. Rec. 219, 113-126. doi: 10.1002/ar.1092190203

Nanci, A., and Smith, C. E. (1992). "Development and calcification of enamel," in Calcification in Biological Systems, ed E. Bonucci (Boca Raton, FL: CRC Press), 313-343.

Nanci, A., and Warshawsky, H. (1984). Characterization of putative secretory sites on ameloblasts of the rat incisor. Am. J. Anat. 171, 163-189. doi: 10.1002/aja.1001710204

Nanci, A., Zalzal, S., and Kan, F. W. (1993). High-resolution scanning electron microscopy of rat incisor ameloblasts. Scanning Microsc. 7, 165-174; discussion 174-175.

Nelson, N., Perzov, N., Cohen, A., Hagai, K., Padler, V., and Nelson, H. (2000). The cellular biology of proton-motive force generation by V-ATPases. J. Exp. Biol. 203(Pt 1), 89-95.

Ng, E. L., Wang, Y., and Tang, B. L. (2007). Rab22B's role in trans-Golgi network membrane dynamics. Biochem. Biophys. Res. Commun. 361, 751-757. doi: 10.1016/j.bbrc.2007.07.076

Nishikawa, S., and Sasaki, F. (1996). Phagocytotic processing of apoptotic bodies of transitional ameloblasts by MHC Class II-expressing macrophages in rat incisor. J. Histochem. Cytochem. 44, 1459-1467. doi: 10.1177/44.12.8985138

Nishio, C., Wazen, R., Kuroda, S., Moffatt, P., and Nanci, A. (2010). Expression pattern of odontogenic ameloblast-associated and amelotin during formation and regeneration of the junctional epithelium. Eur. Cell. Mater. 20, 393-402. doi: 10.22203/eCM.v020a32

Núñez, S. M., Chun Y. H., Ganss, B., Hu, Y., Richardson, A. S., Schmitz, J. E., Simmer, J. P. et al. (2016). Maturation stage enamel malformations in Amtn and Klk4 null mice. Matrix Biol. 52-54, 219-233. doi: 10.1016/j.matbio.2015.11.007

Ohkuma, S., Moriyama, Y., and Takano, T. (1982). Identification and characterization of a proton pump on lysosomes by fluorescein-isothiocyanatedextran fluorescence. Proc. Natl. Acad. Sci. U.S.A. 79, 2758-2762. doi: 10.1073/pnas.79.9.2758

Ostermann, N., Gerhartz, B., Worpenberg, S., Trappe, J., and Eder, J. (2004). Crystal structure of an activation intermediate of cathepsin E. J. Mol. Biol. 342, 889-899. doi: 10.1016/j.jmb.2004.07.073

Ozawa, H., Yamada, M., Uchida, T., Yamamoto, T., and Takano, Y. (1983). "Fine structural and cytochemical studies of the Golgi-SER system of ameloblasts with special reference to its resorptive function," in Mechanisms of Tooth Enamel Formation, ed S. Suga (Tokyo: Quintessence), 17-48. 
Pandey, K. N. (2009). Functional roles of short sequence motifs in the endocytosis of membrane receptors. Front. Biosci. 14, 5339-5360. doi: 10.2741/3599

Pearse, B. M. (1975). Coated vesicles from pig brain: purification and biochemical characterization. J. Mol. Biol. 97, 93-98. doi: 10.1016/S0022-2836(75)80024-6

Pearse, B. M. (1976). Clathrin: a unique protein associated with intracellular transfer of membrane by coated vesicles. Proc. Natl. Acad. Sci. U.S.A. 73, 1255-1259. doi: 10.1073/pnas.73.4.1255

Pearse, B. M., Smith, C. J., and Owen, D. J. (2000). Clathrin coat construction in endocytosis. Curr. Opin. Struct. Biol. 10, 220-228. doi: 10.1016/S0959-440X(00)00071-3

Pelkmans, L., Fava, E., Grabner, H., Hannus, M., Habermann, B., Krausz, E., et al. (2005). Genome-wide analysis of human kinases in clathrin- and caveolae/raftmediated endocytosis. Nature 436, 78-86. doi: 10.1038/nature03571

Peralta, E. R., Martin, B. C., and Edinger, A. L. (2010). Differential effects of TBC1D15 and mammalian Vps39 on Rab7 activation state, lysosomal morphology, and growth factor dependence. J. Biol. Chem. 285, 16814-16821. doi: 10.1074/jbc.M110.111633

Peranen, J. (2011). Rab8 GTPase as a regulator of cell shape. Cytoskeleton 68, 527-539. doi: $10.1002 / \mathrm{cm} .20529$

Peter, M., Chavrier, P., Nigg, E. A., and Zerial, M. (1992). Isoprenylation of rab proteins on structurally distinct cysteine motifs. J. Cell Sci. 102(Pt 4), 857-865.

Plemel, R. L., Lobingier, B. T., Brett, C. L., Angers, C. G., Nickerson, D. P., Paulsel, A., et al. (2011). Subunit organization and Rab interactions of Vps-C protein complexes that control endolysosomal membrane traffic. Mol. Biol. Cell 22, 1353-1363. doi: 10.1091/mbc.E10-03-0260

Plutner, H., Cox, A. D., Pind, S., Khosravi-Far, R., Bourne, J. R., Schwaninger, R., et al. (1991). Rablb regulates vesicular transport between the endoplasmatic reticulum and successive Golgi compartments. J. Cell Biol. 115, 31-43. doi: $10.1083 /$ jcb.115.1.31

Polo, S., and Di Fiore, P. P. (2006). Endocytosis conducts the cell signaling orchestra. Cell 124, 897-900. doi: 10.1016/j.cell.2006.02.025

Poteryaev, D., Datta, S., Ackema, K., Zerial, M., and Spang, A. (2010). Identification of the switch in early-to-late endosome transition. Cell 141, 497-508. doi: 10.1016/j.cell.2010.03.011

Progida, C., Cogli, L., Piro, F., De Luca, A., Bakke, O., and Bucci, C. (2010). Rab7b controls trafficking from endosomes to the TGN. J. Cell Sci. 123(Pt 9), 1480-1491. doi: 10.1242/jcs.051474

Proikas-Cezanne, T., Gaugel, A., Frickey, T., and Nordheim, A. (2006). Rab14 is part of the early endosomal clathrin-coated TGN microdomain. FEBS Lett. 580, 5241-5246. doi: 10.1016/j.febslet.2006.08.053

Racoosin, E. L., and Swanson, J. A. (1992). M-CSF-induced macropinocytosis increases solute endocytosis but not receptor-mediated endocytosis in mouse macrophages. J. Cell Sci. 102(Pt 4), 867-880.

Reith, E. J. (1967). The early stage of amelogenesis as observed in molar teeth of young rats. J. Ultrastruct. Res. 17, 503-526. doi: 10.1016/S0022-5320(67)80138-2

Reith, E. J., and Cotty, V. F. (1967). The absorptive activity of ameloblasts during the maturation of enamel. Anat. Rec. 157, 577-588. doi: 10.1002/ar.1091570404

Rink, J., Ghigo, E., Kalaidzidis, Y., and Zerial, M. (2005). Rab conversion as a mechanism of progression from early to late endosomes. Cell 122, 735-749. doi: 10.1016/j.cell.2005.06.043

Rodriguez-Gabin, A. G., Cammer, M., Almazan, G., Charron, M., and Larocca, J. N. (2001). Role of rRAB22b, an oligodendrocyte protein, in regulation of transport of vesicles from trans Golgi to endocytic compartments. J. Neurosci. Res. 66, 1149-1160. doi: 10.1002/jnr.1253

Rodriguez-Gabin, A. G., Yin, X., Si, Q., and Larocca, J. N. (2009). Transport of mannose-6-phosphate receptors from the trans-Golgi network to endosomes requires Rab31. Exp. Cell Res. 315, 2215-2230. doi: 10.1016/j.yexcr.2009.03.020

Roth, T. F., and Porter, K. R. (1964). Yolk protein uptake in the oocyte of the mosquito Aedes aegypti L. J. Cell Biol. 20, 313-332. doi: 10.1083/jcb.20.2.313

Rubino, M., Miaczynska, M., Lippe, R., and Zerial, M. (2000). Selective membrane recruitment of EEA1 suggests a role in directional transport of clathrin-coated vesicles to early endosomes. J. Biol. Chem. 275, 3745-3748. doi: 10.1074/jbc.275.6.3745

Rudenko, G., Bonten, E., d'Azzo, A., and Hol, W. G. (1995). Three-dimensional structure of the human 'protective protein': structure of the precursor form suggests a complex activation mechanism. Structure 3, 1249-1259. doi: 10.1016/S0969-2126(01)00260-X
Russell, M. R., Nickerson, D. P., and Odorizzi, G. (2006). Molecular mechanisms of late endosome morphology, identity and sorting. Curr. Opin. Cell Biol. 18, 422-428. doi: 10.1016/j.ceb.2006.06.002

Saheki, Y., and De Camilli, P. (2012). Synaptic vesicle endocytosis. Cold Spring Harb. Perspect. Biol. 4:a005645. doi: 10.1101/cshperspect.a005645

Salama, A. H., Bailey, R. L., Eisenmann, D. R., and Zaki, A. E. (1990a). Quantitative cytochemistry of lysosomal structures in rat incisor maturation enamel organ. Arch. Oral Biol. 35, 535-539. doi: 10.1016/0003-9969(90)90084-N

Salama, A. H., Zaki, A. E., and Eisenmann, D. R. (1989). Tubular lysosomes in ruffle-ended ameloblasts associated with enamel maturation in rat incisor. $J$. Histochem. Cytochem. 37, 801-811. doi: 10.1177/37.6.2542393

Salama, A. H., Zaki, A. E., and Eisenmann, D. R. (1990b). Tubular lysosomes in papillary cells during maturation of enamel in the rat. Arch. Oral Biol. 35, 119-126. doi: 10.1016/0003-9969(90)90173-8

Salminen-Mankonen, H. J., Morko, J., and Vuorio, E. (2007). Role of cathepsin $\mathrm{K}$ in normal joints and in the development of arthritis. Curr. Drug Targets 8, 315-323. doi: 10.2174/138945007779940188

Sasaki, T. (1983a). Ultrastructure and cytochemistry of the Golgi apparatus and related organelles of the secretory ameloblasts of the rat incisor. Arch. Oral Biol. 28, 895-905. doi: 10.1016/0003-9969(83)90084-5

Sasaki, T. (1983b). Ultrastructure and cytochemical studies of resorptive and digestive functions of secretory ameloblasts in kitten tooth germs. Acta Anat. 115, 361-375. doi: $10.1159 / 000145713$

Sasaki, T. (1984a). Tracer, cytochemical, and freeze-fracture study on the mechanisms whereby secretory ameloblasts absorb exogenous proteins. Acta Anat. 118, 23-33. doi: 10.1159/000145817

Sasaki, T. (1984b). Morphology and function of maturation ameloblasts in kitten tooth germs. J. Anat. 138, 333-342.

Sasaki, T. (1984c). Endocytotic pathways at the ruffled borders of rat maturation ameloblasts. Histochemistry 80, 263-268. doi: 10.1007/BF00495775

Sasaki, T., and Higashi, S. (1983). A morphological, tracer and cytochemical study of the role of the papillary layer of the rat-incisor enamel organ during enamel maturation. Arch. Oral Biol. 28, 201-210. doi: 10.1016/0003-9969(83)90148-6

Sasaki, T., Higashi, S., Tachikawa, T., and Yoshiki, S. (1983a). Morphology and permeability of junctional complexes in maturing ameloblasts of rat incisors. Acta Anat. 116, 74-83. doi: 10.1159/000145728

Sasaki, T., Higashi, S., Tachikawa, T., and Yoshiki, S. (1983b). Thin-section, tracer, and freeze-fracture study of the smooth-ended maturation ameloblasts in rat incisors. Acta Anat. 117, 303-313. doi: 10.1159/000145802

Schmitz, J. E., Teepe, J. D., Hu, Y., Smith, C. E., Fajardo, R. J., and Chun, Y. H. P. (2014). Estimating mineral changes in enamel formation by ashing/BSE and microCT. J. Dent. Res. 93, 256-262. doi: 10.1177/0022034513520548

Schuck, S., Gerl, M. J., Ang, A., Manninen, A., Keller, P., Mellman, I., et al. (2007). Rab10 is involved in basolateral transport in polarized Madin-Darby canine kidney cells. Traffic 8, 47-60. doi: 10.1111/j.1600-0854.2006.00506.x

Seachrist, J. L., and Ferguson, S. S. (2003). Regulation of G protein-coupled receptor endocytosis and trafficking by Rab GTPases. Life Sci. 74, 225-235. doi: 10.1016/j.lfs.2003.09.009

Segev, N. (2001). Ypt/rab gtpases: regulators of protein trafficking. Sci. STKE 2001:re11. doi: 10.1126/stke.2001.100.re11

Shapiro, J. L., Wen, X., Okamoto, C. T., Wang, H. J., Lyngstadaas, S. P., Goldberg, M., et al. (2007). Cellular uptake of amelogenin, and its localization to CD63, and Lamp1-positive vesicles. Cell. Mol. Life Sci. 64, 244-256. doi: 10.1007/s00018-006-6429-4

Shen, F., and Seabra, M. C. (1996). Mechanism of digeranylgeranylation of Rab proteins. Formation of a complex between monogeranylgeranyl-Rab and Rab escort protein. J. Biol. Chem. 271, 3692-3698. doi: 10.1074/jbc.271.7.3692

Shewale, J. G., and Tang, J. (1984). Amino acid sequence of porcine spleen cathepsin D. Proc. Natl. Acad. Sci. U.S.A. 81, 3703-3707. doi: 10.1073 pnas.81.12.3703

Short, B., Preisinger, C., Schaletzky, J., Kopajtich, R., and Barr, F. A. (2002). The Rab6 GTPase regulates recruitment of the dynactin complex to Golgi membranes. Curr. Biol. 12, 1792-1795. doi: 10.1016/S0960-9822(02)01221-6

Simmelink, J. W. (1982). Mode of enamel matrix secretion. J. Dent. Res. 61, $1483-1488$.

Simmer, J. P., Hu, Y., Lertlam, R., Yamakoshi, Y., and Hu, J. C. (2009). Hypomaturation enamel defects in Klk4 knockout/LacZ knockin mice. J. Biol. Chem. 284, 19110-19121. doi: 10.1074/jbc.M109.013623 
Smith, C. E. (1979). Ameloblasts: secretory and resorptive functions. J. Dent. Res. 58, 695-707. doi: 10.1177/002203457905800221011

Smith, C. E. (1998). Cellular and chemical eventsduring enamel maturation. Crit. Rev. Oral Biol. Med. 9, 128-161. doi: 10.1177/10454411980090020101

Smith, C. E., Hu, Y., Hu, J. C., and Simmer, J. P. (2016). Ultrastructure of early amelogenesis in wild-type, Amelx ${ }^{-/}$, and $\mathrm{Enam}^{-/-}$mice: enamel ribbon initiation on dentin mineral and ribbon orientation by ameloblasts. Mol. Genet. Genomic Med. 4, 662-683. doi: 10.1002/mgg3.253

Smith, C. E., and Nanci, A. (1996). Protein dynamics of amelogenesis. Anat. Rec. 245, 186-207. doi: 10.1002/(SICI)1097-0185(199606)245:2<186::AID-AR7>3. $0 . \mathrm{CO} ; 2-\mathrm{V}$

Smith, C. E., Pompura, J. R., Borenstein, S., Fazel, A., and Nanci, A. (1989). Degradation and loss of matrix proteins from developing enamel. Anat. Rec. 224, 292-316. doi: 10.1002/ar.1092240219

Smith, C. E., and Warshawsky, H. (1977). Quantitative analysis of cell tunrover in the enamel organ of the rat incisor. Evidence for ameloblast death immediately after enamel matrix secretion. Anat Rec. 187, 63-98. doi: 10.1002/ar.1091870106

Soldati, T., Rancano, C., Geissler, H., and Pfeffer, S. R. (1995). Rab7 and Rab9 are recruited onto late endosomes by biochemically distinguishable processes. $J$. Biol. Chem. 270, 25541-25548. doi: 10.1074/jbc.270.43.25541

Somogyi-Ganss, E., Nakayama, Y., Iwasaki, K., Nakano, Y., Stolf, D., McKee, M. D., et al. (2012). Comparative temporospatial expression profiling of murine amelotin protein during amelogenesis. Cells Tissues Organs 195, 535-549. doi: $10.1159 / 000329255$

Somsel Rodman, J., and Wandinger-Ness, A. (2000). Rab GTPases coordinate endocytosis. J. Cell Sci. 113(Pt 2), 183-92.

Sorkin, A. (2004). Cargo recognition during clathrin-mediated endocytosis: a team effort. Curr. Opin. Cell Biol. 16, 392-399. doi: 10.1016/j.ceb.2004.06.001

Sun-Wada, G. H., Wada, Y., and Futai, M. (2004). Diverse and essential roles of mammalian vacuolar-type proton pump ATPase: toward the physiological understanding of inside acidic compartments. Biochim. Biophys. Acta. 1658, 106-114. doi: 10.1016/j.bbabio.2004.04.013

Surmacz, L., Wiejak, J., and Wyroba, E. (2006). Cloning of two genes encoding Rab7 in Paramecium. Acta Biochim. Pol. 53, 149-156.

Swanson, J. A., and Watts, C. (1995). Macropinocytosis. Trends Cell Biol. 5, 424-428. doi: 10.1016/S0962-8924(00)89101-1

Tagliabracci, V. S., Engel, J. L., Wen, J., Wiley, S. E., Worby, C. A., Kinch, L. N., et al. (2012). Secreted kinase phosphorylates extracellular proteins that regulate biomineralization. Science 336, 1150-1153. doi: 10.1126/science.1217817

Takano, Y., and Ozawa, H. (1980). Ultrastructural and cytochemical observations on the alternating morphologic changes of the ameloblasts at the stage of enamel maturation. Arch. Histol. Jpn. 43, 385-399. doi: 10.1679/aohc1950.43.385

Tisdale, E. J., Bourne, J. R., Khosravi-Far, R., Der, C. J., and Balch, W. E. (1992). GTP-binding mutants of rab1 and rab2 are potent inhibitors of vesicular transport from the endoplasmic reticulum to the Golgi complex. J. Cell Biol. 119, 749-761. doi: 10.1083/jcb.119.4.749

Tisdale, E. J., Kelly, C., and Artalejo, C. R. (2004). Glyceraldehyde-3-phosphate dehydrogenase interacts with Rab2 and plays an essential role in endoplasmic reticulum to Golgi transport exclusive of its glycolytic activity. J. Biol. Chem. 279, 54046-54052. doi: 10.1074/jbc.M409472200

Turk, V., Stoka, V., Vasiljeva, O., Renko, M., Sun, T., Turk, B., et al. (2012). Cysteine cathepsins: from structure, function and regulation to new frontiers. Biochim. Biophys. Acta 1824, 68-88. doi: 10.1016/j.bbapap.2011.10.002

Tye, C. E., Lorenz, R. L., and Bartlett, J. D. (2009). Lysosomal protease expression in mature enamel. Cells Tissues Organs 189, 111-114. doi: 10.1159/000151431

Uchida, T., Murakami, C., Wakida, K., Dohi, N., Iwai, Y., Simmer, J. P., et al. (1998). Sheath proteins: synthesis, secretion, degradation and fate in forming enamel. Eur. J. Oral Sci. 106(Suppl. 1), 308-314. doi: 10.1111/j.1600-0722.1998.tb02191.x

Uchida, T., Tanabe, T., and Fukae, M. (1989). Immunocytochemical localization of amelogenins in the deciduous tooth germs of the human fetus. Arch. Histol. Cytol. 52, 543-552. doi: 10.1679/aohc.52.543

Uchida, T., Tanabe, T., Fukae, M., and Shimizu, M. (1991). Immunocytochemical and immunochemical detection of a $32 \mathrm{kDa}$ nonamelogenin and related proteins in porcine tooth germs. Arch. Histol. Cytol. 54, 527-538. doi: $10.1679 /$ aohc. 54.527

Uchida, T., and Warshawsky, H. (1992). Zinc iodine-osmium tetroxide impregnation of the "tubulo-vesicular system" in Tomes' Process of the rat incisor ameloblast. Anat. Rec. 232, 325-339. doi: 10.1002/ar.10923 20302

van der Sluijs, P., Hull, M., Webster, P., Male, P., Goud, B., and Mellman, I. (1992). The small GTP-binding protein rab4 controls an early sorting event on the endocytic pathway. Cell 70, 729-740. doi: 10.1016/0092-8674(92) 90307-X

Villasenor, R., Kalaidzidis, Y., and Zerial, M. (2016). Signal processing by the endosomal system. Curr. Opin. Cell Biol. 39, 53-60. doi: 10.1016/j.ceb.2016.02.002

Wald, T., Spoutil, F., Osickova, A., Prochazkova, M., Benada, O., Kasparek, P., et al. (2017). Intrinsically disordered proteins drive enamel formation via an evolutionarily conserved self-assembly motif. Proc. Natl. Acad. Sci. U.S.A. 114, E1641-E1650. doi: 10.1073/pnas.1615334114

Wang, S. K., Samann, A. C., Hu, J. C., and Simmer, J. P. (2013). FAM20C functions intracellularly within both ameloblasts and odontoblasts in vivo. J. Bone Miner. Res. 28, 2508-2511. doi: 10.1002/jbmr.1990

Warshawsky, H. (1968). The fine structure of secretory ameloblasts in rat incisors. Anat. Rec. 161, 211-229. doi: 10.1002/ar.10916 10207

Weinstock, A., and Leblond, C. P. (1971). Elaboration of the matrix glycoproteins of enamel by the secretory ameloblasts of the rat incisor as revealed by radioautography after galactose-H3 injection. J. Cell Biol. 51, 26-51. doi: $10.1083 /$ jcb.51.1.26

Xu, H., and Ren, D. (2015). Lysosomal physiology. Annu. Rev. Physiol. 77, 57-80. doi: 10.1146/annurev-physiol-021014-071649

Yamashiro, D. J., and Maxfield, F. R. (1987). Acidification of morphologically distinct endosomes in mutant and wild-type Chinese hamster ovary cells. J. Cell Biol. 105(6 Pt 1), 2723-2733. doi: 10.1083/jcb.105.6.2723

Yin, K., Lin, W., Guo, J., Sugiyama, T., Snead, M. L., Hacia, J. G., et al. (2017). MiR153 regulates amelogenesis by targeting endocytotic and endosomal/lososomal pathway-novel insight into the origins of enamel pathologies. Sci. Rep. 7:44118. doi: $10.1038 /$ srep44118

Zahraoui, A., Touchot, N., Chardin, P., and Tavitian, A. (1989). The human Rab genes encode a family of GTP-binding proteins related to yeast YPT1 and SEC4 products involved in secretion. J. Biol. Chem. 264, 12394-12401.

Zerial, M., and McBride, H. (2001). Rab proteins as membrane organizers. Nat. Rev. Mol. Cell Biol. 2, 107-117. doi: 10.1038/35052055

Conflict of Interest Statement: The authors declare that the research was conducted in the absence of any commercial or financial relationships that could be construed as a potential conflict of interest.

Copyright $\odot 2017$ Pham, Smith, Hu, Hu, Simmer and Chun. This is an open-access article distributed under the terms of the Creative Commons Attribution License (CC $B Y)$. The use, distribution or reproduction in other forums is permitted, provided the original author(s) or licensor are credited and that the original publication in this journal is cited, in accordance with accepted academic practice. No use, distribution or reproduction is permitted which does not comply with these terms. 